\title{
Post-CITIZENS UNITED: Using Shareholder Derivative Claims of Corporate Waste to Challenge CORPORATE INDEPENDENT Political ExPEnditures
}

\author{
William Alan Nelson II, Esq.*
}

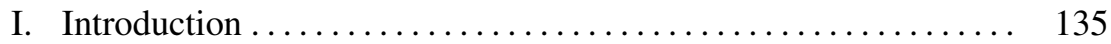

II. Corporate Waste Doctrine ........................ 138

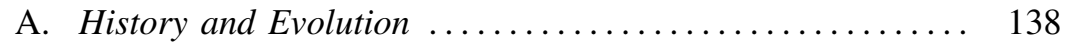

B. Standard for Pleading ........................ 139

III. Corporate Discretion to Refrain from Profit-Maximizing

Activity..................................... 141

A. Statutory Law ................................. 141

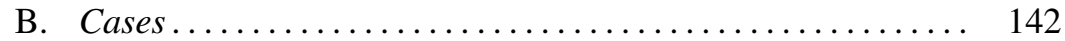

1. Shlensky v. Wrigley ....................... 142

2. A. P. Smith Manufacturing Company v. Barlow...... 143

3. Theodora Holding Corporation v. Henderson .......... 143

4. Kahn v. Sullivan............................. 144

IV. Corporate Political Expenditures ....................... 144

A. Transparency of Political Expenditures .............. 145

1. Shareholder Proposals......................... 147

2. Corporate Response..................... 148

3. Shareholders' Power to Discover Corporate Political

Expenditures ............................. 149

B. Political Expenditures as Corporate Waste ............. 151

1. Cases ................................ 151

i. Stern v. General Electric Company ............ 151

ii. Marsili v. Pacific Gas and Electric Company..... 153

iii. Supreme Court's View .................... 154

V. Challenging Corporate Independent Political Expenditures .... 155

A. Shareholder Arguments ....................... 155

1. Independent Political Expenditures Damage

Corporations ............................ 155

i. Decrease in Shareholder Return ............ 158

ii. Lack of Due Diligence.................. 158

* Professorial Lecturer in Law, George Washington University Law School; AttorneyAdvisor and Judicial Law Clerk, Board of Veterans' Appeals, Department of Veterans Affairs; Articles Editor, Veterans Law Review; Managing Associate Editor, Wealth Strategies Journal; Member, Legal Writing Institute. 
2. Independent Political Expenditures as Corporate Gifts . 159

3. Independent Political Expenditures are not Charitable . 161

4. Independent Political Expenditures Serve No Corporate Purpose ............................... 162

VI. Issues for the Courts ............................ 163

A. Defining "Benefit" to the Corporation............... 164

B. Defining "Business Purpose" .................... 166

VII. Improving Corporate Political Expenditure Policies ......... 167

A. Proposed Model Code for Political Expenditures ......... 167

1. Political Motivations ....................... 168

2. Clearly Defined Criteria for Funds Spent on Political Activities ................................ 169

3. Public Disclosure of Corporate Funds Spent on Political Activities .......................... 170

4. Monitoring Corporate Funds Spent on Political

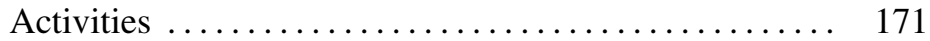

VIII. Conclusion .................................. 172

\section{INTRODUCTION}

This Article discusses how shareholders may bring derivative claims to challenge corporate independent political expenditures they believe are detrimental to the corporation. The Supreme Court's decision in Citizens United v. $F E C^{1}$ removes the prohibition on corporate independent political expenditures and allows companies to spend unlimited sums to expressly advocate the election or defeat of a political candidate. ${ }^{2}$ A recent case from the Montana Supreme Court, Western Tradition Partnership, Inc. v. Attorney General, held that Citizens United did not apply to state elections; ${ }^{3}$ however, the Supreme Court granted certiorari and summarily reversed the Montana Supreme Court in American Tradition Partnership, Inc. v. Bullock. ${ }^{4}$ The U.S. Supreme Court held that "Montana's arguments in support of the judgment [in Western Tradition Partnership] either were already rejected in Citizens United, or fail to meaningfully distinguish that case." ${ }^{5}$ The U.S. Court of Appeals for the D.C. Circuit in SpeechNow.org v. FEC $C^{6}$ and Emily's List v. FEC ${ }^{7}$ established that

1 Citizens United v. Fed. Election Comm'n, 130 S. Ct. 876 (2010). The Court held that “the Government may not suppress political speech on the basis of the speaker's corporate identity. No sufficient governmental interest justifies limits on the political speech of nonprofit or for-profit corporations." Id. at 913. It is important to note that the Citizens United decision did not alter the Congressional prohibitions on direct corporate or union contributions to candidates as upheld by Buckley v. Valeo, 424 U.S. 1 (1976). Id. at 908.

2 See id. at 913 . Independent political expenditure is defined as "an expenditure by a person expressly advocating the election or defeat of a clearly identified candidate; and that is not made in concert or cooperation with or at the request or suggestion of such candidate, the candidate's authorized political committee, or their agents, or a political party committee or its agents." 2 U.S.C. § 431(17) (2006).

3 W. Tradition P'ship v. Attorney Gen., 271 P.3d 1, 13 (Mont. 2011).

4 Am. Tradition P'ship v. Bullock, 132 S. Ct. 2490, 2491 (2012) (per curiam).

5 Id.

6 SpeechNow.org v. Fed. Election Comm'n, 599 F.3d 686, 695 (D.C. Cir. 2010).

7 Emily's List v. Fed. Election Comm'n, 581 F.3d 1, 11 (D.C. Cir. 2009). 
groups that sponsor independent campaign advocacy ("Super PACs") can collect unlimited contributions from their supporters. ${ }^{9}$ Subsequently, in July 2010, the Federal Election Commission (FEC) issued an Advisory Opinion stating that Super PACs "may solicit and accept unlimited contributions from individuals, political committees, corporations, and labor organizations."10

Based on the case law discussed above, corporations are no longer restrained from engaging in independent political spending. This issue has taken center stage in American politics, particularly during the 2012 presidential primaries and general election. "The demand for corporate political dollars has mushroomed in tandem with the dramatically increasing costs of recent American political campaigns." 11

In response to the Citizens United decision, members of Congress proposed legislation to amend the Federal Election Campaign Act of 1971. The Democracy Is Strengthened by Casting Light On Spending in Elections (DISCLOSE) Act stated that its purpose was to "prohibit foreign influence in Federal elections, to prohibit government contractors from making expenditures with respect to such elections, and to establish additional disclosure requirements with respect to spending in such elections." ${ }^{12}$ Democrats introduced the DISCLOSE Act in the House of Representatives on April 29, 2010, ${ }^{13}$ and in the Senate on July 21, 2010. ${ }^{14}$ But the bill died in the Senate. ${ }^{15}$ Two years later, Democrats re-introduced the legislation as the DISCLOSE Act of 2012. ${ }^{16}$ The Senate Republican filibuster again blocked the bill. ${ }^{17}$

Additional reasons that corporate campaign spending is an important issue include the number of people it affects and the amount of money involved. "Roughly half of American households own stocks, many through mutual funds or $401(\mathrm{k})$ retirement accounts. 'Corporate money' in a publicly traded

8 See 2 U.S.C. $\$ 431(17)$ (2006) (defining what "independent [campaign] expenditure[s]" are).

9 FEC Approves Advisory Opinions for Independent Expenditure Committees, OMB WATCH (July 27, 2010), http://www.ombwatch.org/node/11164.

10 FEC Advisory Op. 2010-11 (July 22, 2010), available at http://saos.nictusa.com/aodocs/ AO\%202010-11.pdf.

11 SEC Comment, Petition to Require Public Companies to Disclose Corporate Political Spending File No. 4-637, Dec. 21, 2011, available at http://brennan.3cdn.net/3bd0c2824998 729956_9km6ib1hx.pdf.

12 DISCLOSE Act, H.R. 5175, 111th Cong. (2010), 2009 CONG US HR 5175 (Westlaw). 13 Id.

14 DISCLOSE Act, S. 3628, 111th Cong. (2010), 2009 CONG US S 3628 (Westlaw).

15 See Rosalind S. Helderman, DISCLOSE Act, New Donor Transparency Law, Blocked in Senate, WAsh. Post Pol. (July 16, 2012, 6:45 PM), http://www.washingtonpost.com/blogs/ 2chambers/post/disclose-act-new-donor-transparency-law-blocked-in-senate/2012/07/16/gJ QAbm7WpW_blog.html. Cloture is required to move past a Senate filibuster or the threat of a filibuster and takes a three-fifths vote. In practice, most bills must pass cloture to move forward in the Senate. See Richard S. Beth \& Stanley Bach, Cong. Research Serv., RL30360, Filibusters and Cloture in the Senate 9-11 (2003).

16 DISCLOSE Act of 2012, H.R. 4010, 112th Cong. § 1 (2012), 2011 CONG US HR 4010 (Westlaw); DISCLOSE Act of 2012, S. 3369, 112th Cong. § 1 (2012), 2011 CONG US S 3369 (Westlaw).

17 Ted Barrett, Senate Republicans Block DISCLOSE Act for Second Straight Day, CNN (July 17, 2012, 8:56 PM), http://www.cnn.com/2012/07/17/politics/senate-disclose-act/ index.html. 
company is in part made up of investments from shareholders. Thus, corporate spending is in reality the spending of investors' money." 18 A 2010 study conducted by The Sunlight Foundation ${ }^{19}$ calculated the effect of Citizens United on the 2010 midterm election and found that "the decision was responsible for adding $\$ 126$ million in undisclosed spending by outside groups and $\$ 60$ million in disclosed spending by outside groups to the midterm election." ${ }^{20}$ In the 2010 mid-term elections, "campaign spending by outside groups increased more than $400 \%$ from the 2006 mid-term election to nearly $\$ 300$ million." ${ }^{21}$ If such spending increased at the same rate in the 2012 election cycle, corporate political expenditures will total more than $\$ 1$ billion. ${ }^{22}$ As of July 2012, campaign spending had actually surpassed the $\$ 1$ billion mark and experts predict that the final total could be as high as $\$ 3$ billion. $^{23}$

This raises several important questions: Even though corporations have the power to engage in independent political spending, is it wise for those corporations to do so? What if shareholders believe that corporate spending on political activity is detrimental to the corporation? Will shareholders be informed if the corporation has engaged in corporate spending on political activity? What options are available to minority shareholders who disagree with a corporation's political expenditures?

This Article endeavors to answer these questions and discusses how shareholders can use derivative claims of corporate waste to challenge independent political expenditures that they believe are detrimental to the corporation. The Article begins by discussing the history of the corporate waste doctrine and looks at the standard for pleading a claim of corporate waste. The Article then transitions into a discussion of statutory and case law defining corporate discretion to refrain from profit-maximizing activity, primarily looking at charitable donations.

18 Ciara Torres-Spelliscy, Corporate Campaign Spending: Giving Shareholders a Voice, Brennan Center for Justice, at 5 (2010), http://brennan.3cdn.net/54a676e481f019bfb8_b vm6ivakn.pdf (internal citations omitted).

19 The Sunlight Foundation is a non-profit organization with the goal of increasing transparency and accountability in the United States government. See Our Mission, Sundight FoundATION, http://sunlightfoundation.com/about/ (last visited Nov. 16, 2012).

${ }^{20}$ Nancy J. Whitmore, Facing the Fear: A Free Market Approach for Economic Expression, 17 Cомм. L. \& Pol'y 21, 60 (2012) (citing Paul Blumenthal, The Citizens United Effect: 40 Percent of Outside Money Made Possible by Supreme Court Ruling, SunLight Foundation (Nov. 4, 2010, 1:43 PM), http://sunlightfoundation.com/blog/2010/11/04/thecitizens-united-effect-40-percent-of-outside-money-made-possible-by-supreme-court-ruling/ ) .

21 Andrew C. Byrnes \& Cortlin H. Lannin, I Went Down to the Crossroads: Lifting the Blindfold About the Origin of 501(c)(4) Political Advertisements, 46 U.S.F. L. Rev. 481, 483 (2011).

22 See 12 Months After: The Effects of Citizens United on Elections and the Integrity of the Legislative Process, Public Citizen 9 (2011), http://www.citizen.org/documents/CitizensUnited-20110113.pdf [Hereinafter Public Citizen]; See also Anne Tucker, Rational Coercion: Citizens United and a Modern Day Prisoner's Dilemma, 27 GA. ST. U. L. Rev. 1105, 1127-29 (2011) ("Citizens United has established an environment that exacerbates the pressure on corporations to participate politically through independent expenditures.").

${ }^{23}$ Fredreka Schouten, Presidential Campaign Fundraising Surpasses \$1 Billion, USA ToDAY (July 19, 2012, 10:04 PM), http://www.usatoday.com/news/politics/story/2012-0719/presidential-campaign-fundraising/56347840/1. 
The Article then discusses the issue of the lack of transparency of a corporation's political expenditures and the evolution of case law concerning shareholders using the corporate waste doctrine to invalidate corporate political expenditures. ${ }^{24}$ The Article suggests that shareholders file a request for corporate records as a prerequisite to filing a derivative action and provides arguments shareholders should make when challenging corporate independent political expenditures. The Article concludes by discussing approaches that courts may use to determine the "benefit" and "business purpose" of these independent political expenditures and proposes a model corporate political expenditure program, including creation of a Political Spending Compliance Committee.

\section{Corporate Waste Doctrine}

\section{A. History and Evolution}

The Supreme Court first recognized the corporate waste doctrine in 1933 in Rogers v. Hill. ${ }^{25}$ In Rogers, a shareholder filed suit to compel corporate officers to account for money received as extra compensation and to enjoin further payments. ${ }^{26}$ The Court held that corporate waste occurs "[i]f a bonus payment has no relation to the value of services for which it is given," noting that "it is in reality a gift in part, and the majority stockholders have no power to give away corporate property against the protest of the minority." 27

The corporate waste doctrine has continued to evolve since the seminal decision in Rogers. In McQuillen v. National Cash Register Co. ${ }^{28}$ the U.S. District Court of Maryland held that

[i]f the chosen directors, without interests in conflict with the interest of stockholders, act in good faith in fixing salaries or incurring other expenses, their judgment will not ordinarily be reviewed by the courts, however unwise or mistaken it may appear; but this is far from saying that equity will refuse to redress the wrong done to a stockholder by the action or policy of directors . . . which operates to their own personal advantage, without any corresponding benefit to the corporation under their control. $^{29}$

In Gottlieb v. Heyden Chemical Corp. ${ }^{30}$ the Delaware Supreme Court held that "[s]ince a gift may be a gift in part only, a totally inadequate consideration, of course, invokes the same principle as the absence of any at all." ${ }^{31}$ In Michelson v. Duncan, ${ }^{32}$ the Delaware Supreme Court held that

24 The Article focuses on Delaware law. See, e.g., Mullen v. Acad. Life Ins. Co., 705 F.2d 971, 973 n.3 (8th Cir. 1983) (per curiam) ("[C]ourts of other states commonly look to Delaware law . . . for aid in fashioning rules of corporate law.").

25 See Rogers v. Hill, 289 U.S. 582 (1933); see also Harwell Wells, "No Man Can Be Worth \$1,000,000 a Year": The Fight over Executive Compensation in 1930s America, 44 U. RicH. L. REv. 689, 717-720 (2010).

26 Rogers, 289 U.S. at 584-85.

27 Id. at 591-92.

28 McQuillen v. Nat'l Cash Register Co., 27 F. Supp. 639 (D. Md. 1939).

29 Id. at 651 (quoting Wight v. Heublein, 238 F. 321, 324 (4th Cir. 1916)).

30 Gottlieb v. Heyden Chem. Corp., 90 A.2d 660 (Del. 1952).

31 Id. at 665 (citing Rogers, 289 U.S. at 582).

32 Michelson v. Duncan, 407 A.2d 211 (Del. 1979). 
[t]he essence of a claim of waste of corporate assets is the diversion of corporate assets for improper or unnecessary purposes. Although directors are given wide latitude in making business judgments, they are bound to act out of fidelity and honesty in their roles as fiduciaries. . . . It is common sense that a transfer for no consideration amounts to a gift or waste of corporate assets. ${ }^{33}$

In Glazer v. Zapata Corp. ${ }^{34}$ the Delaware Chancery Court held that "[d]irectors are guilty of corporate waste, only when they authorize an exchange that is so one[-]sided that no business person of ordinary, sound judgment could conclude that the corporation has received adequate consideration" and "[i]f reasonable, informed minds might disagree on the question . . . a reviewing court will not attempt to itself evaluate the wisdom of the bargain or the adequacy of the consideration." 35

In Lewis v. Vogelstein, ${ }^{36}$ the Delaware Chancery Court held that corporate waste "entails an exchange of corporate assets for consideration so disproportionately small as to lie beyond the range at which any reasonable person might be willing to trade" and that a claim for corporate waste "is associated with a transfer of corporate assets that serves no corporate purpose; or for which no consideration at all is received. Such a transfer is in effect a gift." ${ }^{37}$ In Sample v. Morgan, the Delaware Chancery Court held that "[c]laims of waste are sometimes misunderstood as being founded on something other than a breach of fiduciary duty.... [T] [Te doctrine of waste is a residual protection for stockholders that polices the outer boundaries of the broad field of discretion afforded directors by the business judgment rule." 38

\section{B. Standard for Pleading}

Under Delaware law, plaintiffs must "make a pre-suit demand on the company's board that it investigate and evaluate whether to bring the claims or to plead particularized facts demonstrating legal excuse from the demand requirement." ${ }^{39}$ Demand-excuse allegations "must comply with stringent requirements of factual particularity that differ substantially from the permissive notice pleadings [and the requirements are] not satisfied by conclusory statements or mere notice pleading." 40 The test for demand futility is a two-fold test:

The first prong of the futility rubric is "whether, under the particularized facts alleged, a reasonable doubt is created that . . . the directors are disinterested and independent." The second prong is whether the pleading creates a reasonable doubt

33 Id. at 217.

34 Glazer v. Zapata Corp., 658 A.2d 176 (Del. Ch. 1993).

35 Id. at 183.

36 Lewis v. Vogelstein, 699 A.2d 327 (Del. Ch. 1997).

37 Id. at 336.

38 Sample v. Morgan, 914 A.2d 647, 669 (Del. Ch. 2007).

39 Order Granting Defendants' Motions to Dismiss the Complaint at 7, Teamsters Local 237 Additional Sec. Benefit Fund v. McCarthy, No. 2011-cv-197841, 2011 WL 4836230, at*3 (Ga. Super. Ct. Sept. 16, 2011).

40 Brehm v. Eisner, 746 A.2d 244, 254 (Del. 2000). It is important to note that the plaintiffs are not required to plead evidence, only "particularized factual statements that are essential to the claim." Id. 
that "the challenged transaction was otherwise the product of a valid exercise of business judgment.",41

In the context of a claim for corporate waste, plaintiffs' pleadings must "meet the stringent requirements of the waste test, i.e., 'an exchange that is so one[-]sided that no business person of ordinary, sound judgment could conclude that the corporation has received adequate consideration." "42 In In re Citigroup Inc. Shareholder Derivative Litigation, the Delaware Chancery Court held that "plaintiffs [must] plead facts overcoming the presumption of good faith by showing 'an exchange that is so one[-]sided that no business person of ordinary, sound judgment could conclude that the corporation has received adequate consideration." "43

Delaware courts have established a very high burden for shareholders filing derivative claims for corporate waste. ${ }^{44}$ In White v. Panic, the Delaware Supreme Court found that "a corporate waste claim must fail if "there is any substantial consideration received by the corporation, and ... there is a good faith judgment that in the circumstances the transaction is worthwhile." "45 The court also stated that even if the transaction appears to be unreasonably risky, that is not enough to meet the high burden imposed on plaintiffs, and noted that " 'courts are ill-fitted to attempt to weigh the 'adequacy' of consideration under the waste standard or, ex post, to judge appropriate degrees of business risk." "46

However, even though there is a high burden for a claim of corporate waste to succeed, there is case law and empirical evidence showing that Delaware courts may permit corporate waste claims to survive the demand stage with little support. In Michelson, the Delaware Supreme Court held that "[c]laims of gift or waste of corporate assets are seldom subject to disposition by summary judgment; and when there are genuine issues of fact as to the existence of consideration, a full hearing is required."47 In Harbor Finance Partners $v$. Huizenga, the Delaware Chancery Court found that claims for corporate waste "with no genuine likelihood of success can make it to discovery and perhaps to trial." 48 In Schreiber v. Carney, even though the claim for corporate waste was barely supported by the record, the Delaware Chancery Court was reluctant to grant summary judgment "without giving [the] plaintiff an opportunity to further develop his claim."49 The court further found that

41 Id. at 256 (quoting Aronson v. Lewis, 473 A.2d 805, 814 (1984)).

42 Id. at 263 (quoting In re Walt Disney Co. Derivative Litig., 731 A.2d 342, 362 (Del. Ch. 1998)).

43 In re Citigroup Inc. Derivative Litig., 964 A.2d 106, 137 (Del. Ch. 2009) (quoting Brehm, 746 A.2d at 263).

44 Zupnick v. Goizueta, 698 A.2d 384, 387 (Del. Ch. 1997) (stating that a claim for waste must meet "an extreme test, very rarely satisfied by a shareholder plaintiff"); see also Binks v. DSL.net, Inc., No. 2823-VCN, 2010 WL 1713629, at*12 (Del. Ch. 2009) (Corporate waste claims are reserved only for the "rare unconscionable case where directors irrationally squander or give away corporate assets." (citation omitted)).

45 White v. Panic, 783 A.2d 543, 554 (Del. 2001) (quoting Brehm, 746 A.2d at 263).

46 Id. (quoting Brehm, 746 A.2d at 263).

47 Michelson v. Duncan, 407 A.2d 211, 223 (Del. 1979).

48 Harbor Fin. Partners v. Huizenga, 751 A.2d 879, 902 (Del. Ch. 1999).

49 Schreiber v. Carney, 447 A.2d 17, 27 (Del. Ch. 1982). 
whether there has been a waste of corporate assets is a question of fact and is not answered by any bright-line rule. ${ }^{50}$

An empirical study completed by Professors Randall S. Thomas and Kenneth J. Martin in 2001 examined all shareholder derivative cases filed in Delaware between 1912 and 2000. The study found that corporate waste claims succeeded in $29 \%$ of cases. ${ }^{51}$ The study defined success as "defeating a motion to dismiss for failure to make demand, [defeating] a motion to dismiss for failure to state a claim ... [defeating] a motion for summary judgment, or prevailing at trial or on appeal." 52 The empirical evidence showed that even though plaintiffs in corporate waste cases faced a high burden, almost one-third of corporate waste claims still advanced past the demand stage. It is also important to note that these numbers do not include claims that were settled outside of court.

\section{Corporate Discretion to Refrain from Profit- MaXimizing ACTIVITY}

In Dodge v. Ford Motor Co., the Michigan Supreme Court stated that a "corporation is organized and carried on primarily for the profit of the stockholders" and that "[t]he powers of the directors are to be employed for that end." ${ }^{53}$ However, scholars have also opined "that business is permitted and encouraged by the law primarily because it is of service to the community rather than because it is a source of profit to its owners." ${ }^{, 54}$ Throughout history, there has been controversy over the nature and purpose of corporations ${ }^{55}$ It is important to note that no corporate statute has stated that the sole purpose of a corporation is to maximize profits for its shareholders. ${ }^{56}$

\section{A. Statutory Law}

"[E]very state has enacted a corporate statute giving managers explicit authority to donate corporate funds for charitable purposes." ${ }^{57}$ Section 122(9) of Delaware's General Corporation Law provides that "[e]very corporation created under this chapter shall have power to: [m]ake donations for the public welfare or for charitable, scientific or educational purposes, and in time of war or other national emergency in aid thereof." 58 Twenty-three states and the Dis-

$50 I d$.

51 Randall S. Thomas \& Kenneth J. Martin, Litigating Challenges to Executive Pay: An Exercise in Futility, Wash. U. L. REv. 569, 608 (2001). This number is compared to 27\% for duty of care claims and $30 \%$ for duty of loyalty claims. Id. at 608-09.

52 Id. at 583.

53 Dodge v. Ford Motor Co., 170 N.W. 668, 684 (Mich. 1919).

54 E. Merrick Dodd, Jr., For Whom are Corporate Managers Trustees?, 45 HaRv. L. Rev. 1145,1149 (1932).

55 See Judd F. Sneirson, Doing Well by Doing Good: Leveraging Due Care for Better, More Socially Responsible Corporate Decisionmaking, 3 Corp. Governance L. Rev. 438, 439 (2007).

56 Einer Elhauge, Sacrificing Corporate Profits in the Public Interest, 80 N.Y.U. L. REv. 733,763 (2005).

57 Id.

58 Del. Code Ann. tit. 8, § 122(9) (West 2006). 
trict of Columbia have provisions which are nearly identical to the Delaware statute. ${ }^{59}$ Nineteen states have provisions governing donations that further the business and affairs of the corporation, which may include political expenditures. ${ }^{60}$

It is important to note that none of these statutes include any limits on the size of the expenditure or restrictions as to whom the expenditure is given, and these statutes provide no guidance as to the reasonableness of such expenditures. ${ }^{61}$ This is a critical distinction that will be made throughout this Article because the question is not whether corporations have the ability to engage in independent political spending, but whether that political spending serves no corporate purpose and whether that political spending is detrimental to the corporation. As will be discussed later in this Article, that is where the shareholders must focus their claims. ${ }^{62}$

\section{B. Cases}

Several cases have discussed whether directors of a corporation can justify a decision based upon non-economic reasons and whether those decisions negatively affected the corporation.

\section{Shlensky v. Wrigley}

In Wrigley, shareholders brought a derivative suit in Illinois against the directors of Chicago National League Ball Club, Inc. ("Cubs") for negligence and mismanagement. ${ }^{63}$ The shareholders alleged that the Cubs were sustaining operating losses from inadequate attendance at Cubs' home games. ${ }^{64}$ The shareholders believed that the poor attendance was due to the fact that Wrigley Field did not have lights and could not host games at night. ${ }^{65}$ The shareholders stated the Cubs had not installed lights at Wrigley Field because the Cubs believed "that the installation of lights and night baseball games will have a deteriorating effect upon the surrounding neighborhood." 66 The shareholders specifically alleged that the Cubs were "acting for a reason or reasons contrary and wholly unrelated to the business interests of the corporation; that such arbi-

59 Faith Stevelman Kahn, Legislatures, Courts and the SEC: Reflections on Silence and Power in Corporate and Securities Law, 41 N.Y.L. Sch. L. Rev. 1107, 1115 n.31 (1997) ("These states include: Alabama, Alaska, Arizona, Arkansas (except requires board approval of charitable contributions), Connecticut, Hawaii, Idaho, Kansas, Illinois, Louisiana, Maryland (except requires board approval of charitable contributions), Michigan, Missouri, Nebraska, Nevada, New Mexico, Ohio, Oklahoma, Pennsylvania, Rhode Island, South Dakota, Texas and West Virginia.").

${ }^{60}$ Id. ("The states . . . include Colorado, Florida, Georgia, Indiana, Iowa, Kentucky, Mississippi, Montana, New Hampshire, North Carolina, Oregon, South Carolina, Tennessee, Vermont, Utah, Virginia, Washington, Wisconsin and Wyoming.").

61 See id. at 1111-14.

62 See infra Part VI(A).

63 Shlensky v. Wrigley, 237 N.E.2d 776, 777 (Ill. App. Ct. 1968).

${ }^{64} I d$.

65 Id.

66 Id. at 778 . 
trary and capricious acts constitute mismanagement and waste of corporate assets." 67

The Illinois Appellate Court held that the shareholders' allegations were just conclusions and not based on well-pleaded facts. ${ }^{68}$ The court could not find that the motives assigned to the Cubs' directors were contrary to the best interests of the corporation and the shareholders. ${ }^{69}$ The court stated that:

[T] he effect on the surrounding neighborhood might well be considered by a director who was considering the patrons who would or would not attend the games if the park were in a poor neighborhood . . . the long run interest of the corporation in its property value at Wrigley Field might demand all efforts to keep the neighborhood from deteriorating. ${ }^{70}$

The Illinois Appellate Court also held that the shareholders failed to allege any damage to the corporation. ${ }^{71}$ The court found that "factors other than attendance affect the net earnings or losses" and no allegation was made to show that the lights would have provided a net benefit to the corporation. ${ }^{72}$ Based upon these facts, the court affirmed the shareholders' claims dismissal. ${ }^{73}$

\section{A. P. Smith Manufacturing Company v. Barlow}

In Barlow, shareholders brought a derivative suit in New Jersey against the directors of the A. P. Smith Manufacturing Company ("Smith Manufacturing") alleging the corporation did not have the power to make a $\$ 1,500$ donation to Princeton University. ${ }^{74}$ The shareholders specifically alleged that Smith Manufacturing's "certificate of incorporation does not expressly authorize the contribution and under common-law principles the company does not possess any implied or incidental power to make it."75

The New Jersey Supreme Court held that the donation was valid. ${ }^{76}$ The court found that the donation was not made indiscriminately or in furtherance of personal rather than corporate ends. ${ }^{77}$ The court further found that the donation "was made to a preeminent institution of higher learning, was modest in amount and well within the limitations imposed by the statutory enactments, and was voluntarily made in the reasonable belief that it would aid the public welfare and advance the interests of the . . corporation." 78

\section{Theodora Holding Corporation v. Henderson}

In Henderson, shareholders brought a derivative suit in Delaware against the directors of the Theodora Holding Corporation ("Theodora Holding") alleging that losses sustained by the corporation were the result of certain transac-

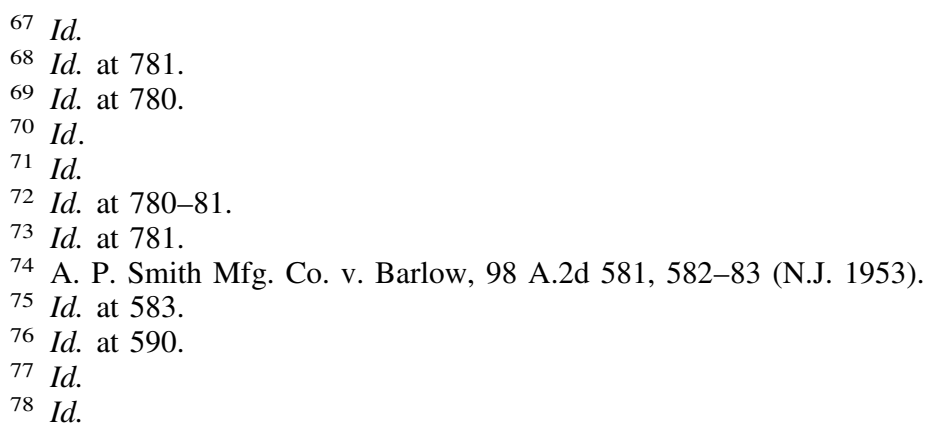


tions, including a charitable donation of $\$ 528,000$ to the Alexander Dawson Foundation. ${ }^{79}$

The Delaware Chancery Court found that for a "corporate charitable or educational gift to be valid [it] must merely be within reasonable limits both as to amount and purpose." 80 The court held that the test to determine the validity of a corporate donation is a test of reasonableness and that "the provisions of the Internal Revenue Code pertaining to charitable gifts by corporations furnish a helpful guide." 81 The court found that the donation made in this case, $\$ 528,000$, fell within the federal tax deduction limitation of $5 \%$ of the corporation's income. ${ }^{82}$ The court further found that

the relatively small loss of immediate income otherwise payable to plaintiff and the corporate defendant's other stockholders, had it not been for the gift in question, is far out-weighed by the overall benefits flowing from the placing of such gift in channels where it serves to benefit those in need of philanthropic or educational support, thus providing justification for large private holdings, thereby benefiting plaintiff in the long run. ${ }^{83}$

\section{Kahn v. Sullivan}

In Kahn, shareholders brought a derivative suit in Delaware against the directors of the Occidental Petroleum Company ("Occidental") challenging a decision by Occidental's board of directors, through a special committee of Occidental's outside directors, to make a charitable donation for the purpose of constructing and funding an art museum. ${ }^{84}$ The shareholders alleged that the donations did not serve a corporate purpose and constituted a waste of corporate assets. ${ }^{85}$

The Delaware Supreme Court held that Occidental's donation was reasonable and not excessive. ${ }^{86}$ The court stated that "not every charitable gift constitutes a valid corporate action," but that "given the net worth of Occidental, its annual net income before taxes, and the tax benefits to Occidental, . . . the gift ... was within the range of reasonableness." ${ }^{87}$ The court further found that Occidental received an economic benefit in the form of good will from the charitable donation and that the corporation would gain an economic benefit from "being able to utilize the [m] useum, adjacent to its corporate headquarters, in the promotion of its business." 88

\section{Corporate Political Expenditures}

Shareholders may file derivative claims of corporate waste against directors of corporations to challenge corporate independent political expenditures

79 Theodora Holding Corp. v. Henderson, 257 A.2d 398, 399-400 (Del. Ch. 1969).

$80 \mathrm{Id}$. at 404.

81 Id. at 405; See also I.R.C $\S 170$ (2006).

82 Henderson, 257 A.2d at 405.

$83 \mathrm{Id}$.

84 Kahn v. Sullivan, 594 A.2d 48, 50 (Del. 1991).

85 Id. at 61.

$86 \mathrm{Id}$.

$87 \mathrm{Id}$.

88 Id. at 62. 
that they believe are detrimental to the corporation. ${ }^{89}$ However, most shareholders are not even aware of their corporation's political expenditures largely because corporations are not required to report them to shareholders in any specific public financial filing. ${ }^{90}$ It is also important to note that corporations do not typically volunteer information concerning political expenditures. ${ }^{91}$ "Investor activists want companies to disclose how they spend corporate treasury money on politics not only because this is their money, but also because of their generally-held belief that political spending can pose risks to shareholder value." 92

\section{A. Transparency of Corporate Political Expenditures}

Federal securities laws do not require that shareholders receive information concerning corporate political spending. ${ }^{93}$ The Securities and Exchange Commission (SEC) does not have any regulations requiring disclosure by publicly-traded companies of their political spending to shareholders. ${ }^{94}$ Even for political expenditures that are properly reported to a government agency, such as the FEC, corporations are not required by law to share that information with shareholders in an accessible way, such as in an annual report. ${ }^{95}$ "Political contributions are generally not disclosed to the board or shareholders, nor are political expenditures generally subject to oversight as part of a corporation's internal controls." "Corporations are [also] not required to report or account for corporate funds donated through third parties." 97

As U.S. law stands, "corporate managers can spend corporate money on politics without notifying shareholders either before or after the fact and they can make this political spending without any authorization from shareholders. ${ }^{\circ 8}$ A 2008 survey, conducted by The Conference Board, ${ }^{99}$ found that $73 \%$ of the 255 directors surveyed wrongly believed that corporations were required

89 See Sample v. Morgan, 914 A.2d 647, 669 (Del. Ch. 2007) ("[T]he doctrine of waste is a residual protection for stockholders that polices the outer boundaries of the broad field of discretion afforded directors by the business judgment rule.").

90 Heidi Welsh \& Robin Young, Corporate Governance of Political Expenditures: 2011 Benchmark Report on S\&P 500 Companies, Sustainable Investments Institute (Si2) 33-34 (2011), http://www.irrcinstitute.org/pdf/Political_Spending_Report_Nov_10_2011. pdf ("Two-thirds of the companies that spend shareowner money fail to tell their investors where and how it is spent.").

91 Id. at $34,43$.

92 Id. at 31.

93 Torres-Spelliscy, supra note 18, at 12.

94 Id.

$95 I d$.

96 Jill E. Fisch, The "Bad Man" Goes to Washington: The Effect of Political Influence on Corporate Duty, 75 Fordham L. Rev. 1593, 1613 (2006).

97 Paul Denicola et al., The Conference Board, Handbook on Corporate PolitiCAl Activity: Emerging Corporate Governance Issues 11 (2010), available at http:// www.politicalaccountability.net/index.php?ht=A/GetDocumentAction/id/4084 [hereinafter Corporate Political Handbook].

98 Torres-Spelliscy, supra note 18 , at 10.

99 The Conference Board is a non-profit, global, independent business membership and research association. See About Us, THE CONFERENCE BOARD, http://www.conference-board. org/about/index.cfm?id=1980 (last visited Nov. 16, 2012). 
to publicly disclose all their political spending, 38\% were unaware that political spending does not require board approval, and $41 \%$ did not know that trade associations are not required to disclose their corporate members or the beneficiaries of their political expenditures. ${ }^{100}$ In that same survey, $60 \%$ of those directors supported requiring board oversight of political expenditures. ${ }^{101}$ These numbers reflect that many directors support more oversight of corporate political expenditures, but overestimate their legal obligations concerning corporate political expenditures.

A November 2011 study conducted by Sustainable Investments Institute ("Si2") ${ }^{102}$ and the Investor Responsibility Research Center Institute ("IRRC") ${ }^{103}$ found that only seven companies (Conoco Phillips, Gilead Sciences, Goldman Sachs, CitiGroup, Ford, Kroger, and Microsoft) mention independent political expenditures in their stated policies. ${ }^{104}$ However, as of October 2011, forty-three Standard \& Poor's (S\&P) 100 companies disclosed at least some information about their indirect spending on their corporate websites. ${ }^{105}$ Twenty-four S\&P 100 companies explicitly stated on their websites that they would not make independent expenditures. ${ }^{106}$ Those numbers appear to indicate that a growing number of companies are realizing the importance of disclosure.

In April 2011, the Los Angeles Times compiled a study on corporate political spending and awarded ratings based upon political spending transparency. ${ }^{107}$ The study "reviewed how the 75 largest publicly traded companies in the energy, healthcare and financial services sectors disclose their political giving on their corporate websites." 108 "Companies were asked about three kinds of political spending - standard political giving to candidates and campaigns, giving to trade associations and giving to other tax-exempt issue advo-

100 Corporate Political Handbook, supra note 97, at 19.

101 Id.; but see Lucian A. Bebchuk \& Robert J. Jackson, Jr., Corporate Political Speech: Who Decides? 6 (Harv. Law \& Economics, Discussion Paper No. 676, 2010), available at http://ssrn.com/abstract=1670085 ("A recent survey reported that, among the one hundred largest public companies in the United States, only thirty-four require board-level approval of political contributions.").

102 "The Sustainable Investment Institute (Si2), a non-profit organization based in Washington, D.C., conducts impartial research and publishes reports on organized efforts to influence corporate behavior on social and environmental issues." Sustainable Investments InstiTUTE, http://www.siinstitute.org (last visited Nov. 16, 2012).

103 IRRC is a non-profit organization that funds environmental, social and corporate governance research, as well as the capital market context that impacts how investors and companies make decisions. IRRC Institute, http://www.irrcinstitute.org (last visited Nov. 16, 2012); see also IRRC Grant Funding, IRRC InSTITUTE, http://www.irrcinstitute.org/about. php?page $=$ grants \&nav=3 (last visited Nov. 16, 2012).

104 Welsh \& Young, supra note 90, at 81-84.

105 Center for Political Accountability, CPA-Zicklin Index of Corporate Political Accountability and Disclosure: How Leading Companies Navigate Political SPENDING IN THE WAKE OF Citizens United 5 (2011), available at http://www.political accountability.net/index.php?ht=A/GetDocumentAction/i/5800.

106 Id.

107 Kim Geiger et al., Corporate Political Transparency Ratings, L.A. TIMEs (Apr. 23, 2011), http://spreadsheets.latimes.com/corporate-transparency-ratings/.

108 Id. 
cacy groups . ..."109 All the information provided by the surveyed companies was checked against their corporate websites and financial filings. ${ }^{110}$ Companies such as Aetna, Humana, American Electric Power, and Exelon, received high ratings for the level of transparency of their political expenditures. ${ }^{111}$ Companies such as Travelers, Murphy Oil, JP Morgan Chase, Halliburton, and Goldman Sachs, all received low ratings for the level of transparency of their political expenditures. ${ }^{112}$

To address this lack of transparency in corporate political spending, the Committee on Disclosure of Corporate Political Spending ${ }^{113}$ in 2011 submitted a petition to the SEC to "develop rules to require public companies to disclose to shareholders the use of corporate resources for political activities." 114 The petition outlines how shareholders are increasingly interested in receiving information about corporate political spending and how transparency in corporate political spending helps ensure accountability. ${ }^{115}$ The petition contends that for the procedures of corporate democracy to work, "shareholders must have information about the company's political speech; otherwise, shareholders are unable to know whether such speech advances the corporation's interest in making profits." 116

\section{Shareholder Proposals}

In recent years, shareholder proposals ${ }^{117}$ concerning political expenditures accounted for approximately $25 \%$ of the proposals filed, and approximately $33 \%$ of the resolutions voted on. ${ }^{118}$ The average support for political expenditure proposals was $32.5 \%$, up from $30.4 \%$ for similar proposals in $2010 .{ }^{119}$ For the 2012 proxy season, Institute Shareholder Services ("ISS") ${ }^{120}$ reported that "[t]he number of resolutions on political issues top[ped] 100, for the first time

109 Corporate Political Transparency Ratings: The Times' Methodology, L.A. Times (Apr. 23, 2011), http://spreadsheets.latimes.com/corporate-transparency-ratings/methodology/.

110 Id.

111 Geiger, supra note 107.

112 Id.

113 A group of ten academics whose teaching and research focus on corporate and securities law. Petition for Rulemaking from Comm. on Disclosure of Corporate Political Spending, to Elizabeth Murphy, Sec'y of the SEC (Aug. 3, 2011), http://www.sec.gov/rules/petitions/ 2011/petn4-637.pdf.

114 Id.

115 See id.

116 Id.

117 Securities Exchange Act Rule 14a-8 enables shareholders to request that the company include their written proposals in the company's proxy materials, for consideration at the annual or special shareholders meeting to which the proxy materials relate. 17 C.F.R. $\S 240.14$ a 8 (2011) ("A shareholder proposal is your recommendation or requirement that the company and/or its board of directors take action, which you intend to present at a meeting of the company's shareholders.").

118 Ted Allen et al., 2011 U.S. Postseason Report 27 (2011), available at http://www. issgovernance.com/files/private/2011_US_PostSeason_Report_0929.pdf.

119 Id.

120 ISS is a provider of corporate governance solutions to the global financial community. Institute Shareholder Services (ISS), http://www.issgovernance.com (last visited Nov. $16,2012)$. 
beating out the environment category as the top social issue proposed for proxy consideration." 121

The main proponent for more transparency in corporate political expenditures is the Center for Political Accountability ("CPA"). For the ninth consecutive year, the CPA is asking companies to report their direct and indirect political contributions. ${ }^{122}$ The CPA is asking for the companies to report on "[p]olicies and procedures for political contributions and expenditures (both direct and indirect) made with corporate funds" and "[m]onetary and non-monetary contributions and expenditures (direct and indirect) used to participate or intervene in any political campaign on behalf of (or in opposition to) any candidate for public office, and used in any attempt to influence the general public, or segments thereof, with respect to elections or referenda." 123

Other examples of shareholders proposing resolutions on political expenditures include NorthStar Asset Management, LLC ("NorthStar") ${ }^{124}$ which is asking companies to adopt a policy establishing "an annual proxy advisory vote on the company's political contribution policies and its planned electioneering expenditures for the next fiscal year." 125 "NorthStar has submitted the resolution to Chubb, Google, Home Depot, Intel, Praxair, and Western Union." 126 Other proposed shareholder resolutions for the 2012 proxy season include a proposal at Johnson \& Johnson to require shareholder approval of contributions ${ }^{127}$ and proposals asking three companies (3M, Bank of America, and Target) to refrain from any political spending. ${ }^{128}$

\section{Corporate Response}

At corporations where shareholder proposals were introduced to require additional reporting requirements concerning political expenditures, corporations have been hesitant to disclose those expenditures in public financial reports. Some corporations have stated that the "collecting and posting of political spending information is burdensome and of no interest to shareholders" and that they may also "not want their competitors to have insight into their political spending programs." 129

For example, The Boeing Co., in its 2010 proxy statement, argued that reporting on its political expenditures would "impose unwarranted administra-

121 Carolyn Mathiasen \& Erik Mell, 2012 U.S. Proxy Season Preview: EnvironmenTAL \& SOCIAL Issues 20 (Mar. 7, 2012), available at http://www.issgovernance.com/files/ private/2012USProxySeasonPreviewES.pdf [hereinafter 2012 ISS PREVIEW REPORT].

122 Id.

123 Id.

124 "NorthStar Asset Management specializes in the individual management of portfolios of private clients, foundations, corporations, and institutions." NORTHSTAR, http://www.northstarmgt.com (last visited Nov. 16, 2012).

1252012 ISS PReview Report, supra note 121, at 21.

126 Id.

127 Id. ("The corporation shall make no political contributions without the approval of the holders of at least $75 \%$ of its shares outstanding.").

128 Id. at 22. Bank of America shareholders argue that "continued political spending could expose the company's already[ ]battered brand to further risk, given its sizable political footprint." Id.

129 Corporate Political Handbook, supra note 97, at 20. 
tive burdens on Boeing with no discernable [sic] benefit to shareholders." 130 Citigroup Inc., in its 2009 proxy statement, argued that disclosing its spending through trade associations "would not provide stockholders with a greater understanding of Citi's strategies or philosophies about its political contributions." 131

Valero Energy Corp., in its 2011 proxy statement, argued that any "additional reporting requirement ... over and beyond the significant initiatives that we have already put in place regarding disclosure of political contributions, would serve no useful purpose, would be burdensome, could lead to misleading representations of our political positions, and would result in unnecessary expense." 132 Occidental Petroleum, in its 2011 proxy statement, argued that its "aggregate political contributions are not financially material to the company and anyone who desires to find information on Occidental's political expenditures could easily do so with a web search of public records. Therefore, providing an additional report is unnecessary." 133

These statements evidence a disconnect between directors and shareholders on the issue of transparency in corporate political spending. However, the urgency for more transparency in this area has multiplied exponentially since the Supreme Court's decision in Citizens United. This issue also bears on a corporation's image as a "good corporate citizen." "Shareholders have legitimate interests in information about corporate policies and practices with respect to ... political contributions[,] ... [and this issue] ... bear[s] on the company's reputation as a good corporate citizen and consequently, the perceived integrity of management and the board." ${ }^{34}$ The issue of transparency will be discussed in greater detail later in this Article. ${ }^{135}$

\section{Shareholders' Power to Discover Corporate Political Expenditures}

Shareholders have certain powers to inspect corporate records to investigate corporate political expenditures, even if a corporation does not disclose those expenditures in public financial filings. Under Delaware law, sharehold-

130 The Boeing Co., Notice of 2010 Annual Meeting and Proxy Statement 69 (2010). The statement also argued that "implementation of the proposal would place Boeing at a competitive disadvantage by requiring the Company to reveal important elements of its corporate strategy. Boeing's competitors could use this information at our shareholders' expense." Id.

131 Citigroup Inc., Notice of Annual Meeting of Stockholders 93 (2009) (“Although Citi is a member of trade associations, the Citi Political Contributions Policy does not cover our giving to trade associations. Because these associations operate independently of their members and take a wide variety of positions on a number of matters, not all of which Citi supports, disclosure of Citi's contributions to these associations would not provide stockholders with a greater understanding of Citi's strategies or philosophies about its political contributions.").

132 Valero Energy Corp., Notice of 2011 Annual Meeting of Stockholders 69 (2011).

133 Occidental Petroleum Corp., Notice of Annual Meeting of Stockholders 79 (2011).

134 Ira M. Millstein, Holly J. Gregory \& Rebecca C. Grapsas, Rethinking Board and Shareholder Engagement in 2008, WeIL, Gotshal \& MANGes LLP 3 (2008), available at http:// www.weil.com/news/pubdetail.aspx?pub $=6382$.

135 See infra Part VII.A.1. 
ers "have the right ... to inspect for any proper purpose ... [t]he corporation's stock ledger, a list of its stockholders, and its other books and records . . ."136 Delaware courts have even urged shareholders to make a books-and-records request before filing a complaint because it might prevent expensive and timeconsuming procedural issues that often occur in derivative litigation. ${ }^{137}$

Shareholders must be aware that they can, and should, file a books-andrecords request as a prerequisite to filing a derivative suit. In Khanna v. Covad Communications Group, the Delaware Chancery Court held that the filing of a derivative action did not preclude a shareholder from bringing an action seeking disclosure of corporate records, since disclosure had originally been demanded long before filing of the derivative action, and the derivative action would not have been necessary if the corporation had properly responded to the demand in a timely manner. ${ }^{138}$ In Paul v. China MediaExpress Holdings, Inc., the court found that what matters in proving a proper purpose under the booksand-records-request statute is that the shareholder would have standing to bring either direct or derivative claims against the corporation following the requested inspection. ${ }^{139}$

"Proper purpose" has been defined as "a purpose reasonably related to the demander's interest" as a shareholder. ${ }^{140}$ In Paul, the Delaware Chancery Court found that the shareholders had stated proper purposes for inspecting a company's books and records because the shareholders submitted evidence that showed a "credible basis" to suspect waste and mismanagement. ${ }^{141}$ In Thomas $\&$ Betts Corp. v. Leviton Manufacturing Co., the Delaware Supreme Court held that even though shareholders must make specific and credible allegations sufficient to warrant a suspicion of waste and mismanagement, shareholders were not required to prove by a preponderance of the evidence that waste and mismanagement were actually occurring. ${ }^{142}$ For a demand to inspect corporate records to be successful, shareholders need only establish "some credible basis" to support an inference of corporate waste. ${ }^{143}$ The Delaware Supreme Court

136 Del. Code AnN. tit. 8, § 220 (West 2010).

137 In re Walt Disney Co. Derivative Litig., 825 A.2d 275, 279 (Del. Ch. 2003); see also King v. VeriFone Holdings, Inc., 12 A.3d 1140, 1145 (Del. 2011) ("Delaware courts have strongly encouraged stockholder-plaintiffs to utilize Section 220 before filing a derivative action, in order to satisfy the heightened demand futility pleading requirements of Court of Chancery Rule 23.1.").

138 Khanna v. Covad Commc'n Grp., No. 20481-NC, 2004 Del. Ch. LEXIS 11, at*10-16 (Del. Ch. Jan. 23, 2004).

139 Paul v. China MediaExpress Holdings, Inc., No. 6570-VCP, 2012 Del. Ch. LEXIS 3, at *18 (Del. Ch. Jan. 5, 2012).

140 Weisman v. W. Pac. Indus., Inc., 344 A.2d 267, 268 (Del. Ch. 1975); see also N.W. Indus., Inc. v. B.F. Goodrich Co., 260 A.2d 428, 429 (Del. 1969).

141 Paul, 2012 Del. Ch. LEXIS 3, at $* 13$.

142 Thomas \& Betts Corp. v. Leviton Mfg. Co., 681 A.2d 1026, 1031 (Del. 1996).

143 See Freund v. Lucent Techs., No. 18893, 2003 Del. Ch. LEXIS 3, at*10 (Del. Ch. Jan. 9, 2003). See also Skouras v. Admiralty Enters., Inc., 386 A.2d 674, 678 (Del. Ch. 1978) (" $[\mathrm{M}]$ ore than a general statement is required in order for the Court to determine the propriety of a demand . . . ."); Helnsman Mgmt. Servs., Inc. v. A \& S Consultants, Inc., 525 A.2d 160, 165-66 (Del. Ch. 1987) ("A mere statement of a purpose to investigate possible general mismanagement, without more, will not entitle a shareholder to broad $\S 220$ inspection relief. There must be some evidence of possible mismanagement as would warrant further investigation of the matter."). 
has noted that "the 'credible basis' standard sets the lowest possible burden of proof." 144

\section{B. Political Expenditures as Corporate Waste}

\section{Cases}

Until recently, corporations were not allowed to engage in independent political spending in federal elections. ${ }^{145}$ Because of the Supreme Court's decision in Citizens United, corporations are now allowed to spend unlimited sums from their treasuries on advertisements that promote or oppose specific candidates. ${ }^{146}$ Also, as noted above, shareholders are often unaware of political spending by the corporation. ${ }^{147}$ Because of the laws in place prohibiting corporations from engaging in independent political spending and the lack of transparency in corporate political spending, there is a dearth of case law on the subject.

\section{i. $\quad$ Stern v. General Electric Company}

In Stern, a shareholder filed a derivative action against the directors of General Electric Company ("GE") alleging that they had expended large sums from the corporation's treasury for the support of the General Electric Political Action Committee ("GE/PAC"). ${ }^{148}$ The shareholder's complaint was that corporate "funds had been used to support congressional incumbents without regard to their past position on business issues, and that this practice was harmful to the interests of GE's shareholders." "49 On appeal, the district court had dismissed the claims for corporate waste on the basis that the allegations of corporate waste were preempted by the Federal Election Campaign Act of 1971 ("FECA"). ${ }^{150}$

The U.S. Court of Appeals for the Second Circuit found that state law claims for corporate waste based upon a corporation's contributions to a federal political campaign were not preempted and held that the FECA did "not preclude New York from pursuing its independent interest in ensuring that corporate directors exercise sound judgment in the expenditure of corporate funds." ${ }^{151}$ However, the Second Circuit granted GE's motion to dismiss the claims for corporate waste, stating that the pleadings were "made upon 'information and belief' and d[id] not identify with particularity the facts upon which the belief [was] founded." ${ }^{52}$ The Second Circuit held that under New York law, " $[t]$ o survive a motion to dismiss . . . a shareholder derivative complaint

144 Seinfeld v. Verizon Commc'n, Inc., 909 A.2d 117, 123 (Del. 2006).

145 Tillman Act, ch. 420, 34 Stat. 864, 864-65 (1907). The Tillman Act made it a crime for corporations to make financial contributions to candidates for federal office. 2 U.S.C. $\S 441$ b(a) (2006) barred direct corporate contributions to the campaigns of federal political candidates and also corporate independent expenditures on their behalf.

146 Citizens United v. Fed. Election Comm'n, 130 S. Ct. 876, 913 (2010).

147 See supra Part IV.A.

148 Stern v. Gen. Elec. Co. (Stern I), 924 F.2d 472, 473 (2d Cir. 1991).

149 Id.

150 Id. at 474.

151 Id. at 475.

152 Id. at 477. 
must allege that the directors acted fraudulently or in bad faith; allegations of 'waste,' standing alone, will not be enough." 153 The Second Circuit dismissed the claims for corporate waste, but with leave to replead. ${ }^{154}$

The plaintiff filed an amended complaint alleging "bad faith on the part of defendants' [sic] in their decisions to continue to expend corporate assets for solicitation and administration costs of GE/PAC, which, [the] plaintiff claim[ed], constituted an improper use and waste of corporate assets." ${ }^{155}$ The U.S. District Court for the Southern District of New York stated that under "New York law, 'the essence of waste is the diversion of corporate assets for improper or unnecessary purposes" "156 and that shareholders "must demonstrate that no person of ordinary sound business judgment would say that the corporation received fair benefit." 157

The decision also stated that courts should make "a determination as to the motives of corporate directors and any personal benefit they might receive in their decisions to expend corporate assets" and that courts may infer that directors have improper motives or were recklessly indifferent to the stockholders' interests "if there is great disparity in values between the assets expended and the benefits received." 158 The New York court found that the allegations contained in the amended complaint, construed in the light most favorable to the plaintiff, ${ }^{159}$ sufficiently pleaded the required elements of a claim for corporate waste. ${ }^{160}$ The court went on to state that it was not making any judgment as to plaintiff's likelihood of success and that the claim must succeed or fail after a thorough discovery process. ${ }^{161}$

Discussing the merits of the claim for corporate waste, the court stated that "to overcome [the] 'business judgment rule', a shareholder must show that 'no person of ordinary sound business judgment would say that the corporation received fair benefit' in exchange for the challenged expenditure." ${ }^{162}$ The shareholders must also show that the directors acted with intent to serve some outside interest, regardless of the consequences. ${ }^{163}$ The New York court laid out a two-part test. First, a court will look at the "benefit to the corporation of the challenged expenditures and the purpose of those expenditures." Second, if the evidence indicates "an improper purpose or that the corporation has not received fair benefit, then the motives behind the corporate directors' decisions will be examined." 164

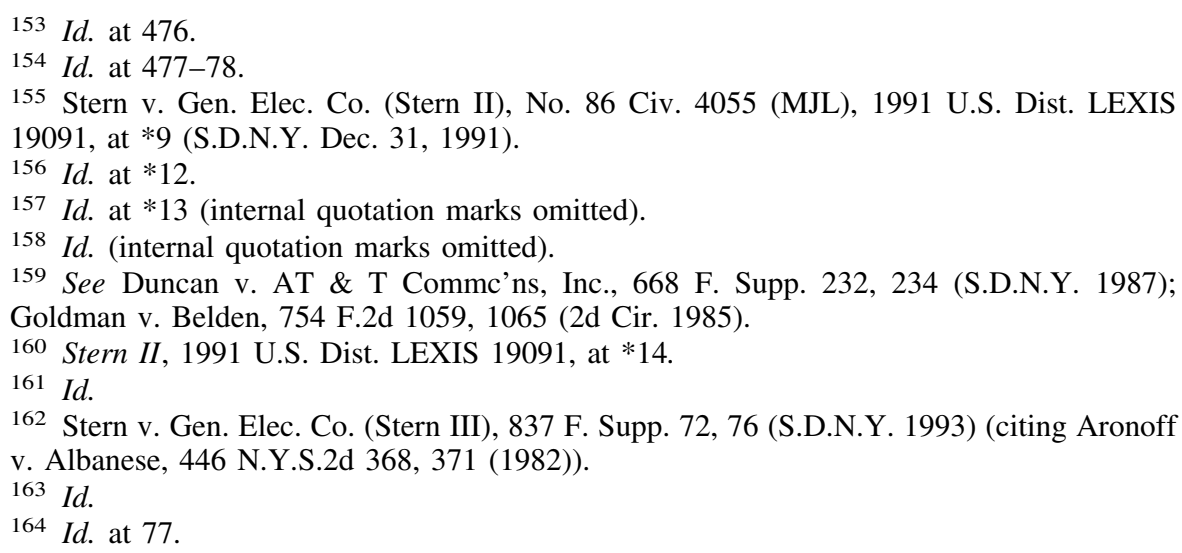


The New York court first looked at the benefit derived by GE from the corporation's support of the GE/PAC. The plaintiff's own expert testified that the GE/PAC had been effective in building good will with members of Congress. ${ }^{165}$ Witnesses also testified the benefits derived from support of GE/PAC included "the involvement and education of GE employees on government relations[,] the election of candidates open to GE's position on various issues[,] and the maintenance and improvement of GE's relationship with members of Congress." 166 The New York court held that the plaintiff was unable to show an absence of benefit to GE resulting from its support of GE/PAC's operation. ${ }^{167}$ The New York court granted the defendants' motion for summary judgment and held that the plaintiff had not shown the purpose of GE/PAC to be improper and that the lawful and beneficial activities of GE/PAC did not result in a waste of corporate assets. ${ }^{168}$

\section{ii. Marsili v. Pacific Gas and Electric Company}

In Marsili, shareholders brought a derivative action challenging a $\$ 10,000$ contribution made by Pacific Gas and Electric Company ("Pacific Gas") to an association advocating the defeat of a proposition appearing on a municipal election ballot. ${ }^{169}$ The ballot initiative at issue would have prohibited construction in San Francisco of any building more than seventy-two feet in height without prior approval of the voters. ${ }^{170}$ Pacific Gas argued that passage of the initiative would have interfered with the construction of necessary company facilities and raised property taxes. ${ }^{171}$ The shareholders argued that the contribution was an ultra vires act and that the contributions were illegal. ${ }^{172}$ The trial court entered summary judgment in favor of Pacific Gas. ${ }^{173}$ The California Court of Appeals affirmed the lower court's decision and found the contribution valid because it was neither gratuitous nor lacking corporate objective. ${ }^{174}$

The California Court of Appeals held that the directors have "discretionary authority to enter into contracts and transactions which may be deemed reasonably incidental to its business purposes" and that "[w]hatever transactions are fairly incidental or auxiliary to the main business of the corporation and necessary or expedient in the protection, care and management of its property may be undertaken." "Neither the court nor minority shareholders can substitute their judgment for that of the corporation 'where its board has acted in good faith and used its best business judgment in behalf of the corporation.' "176 The court found that Pacific Gas had researched the initiative's potential detrimental

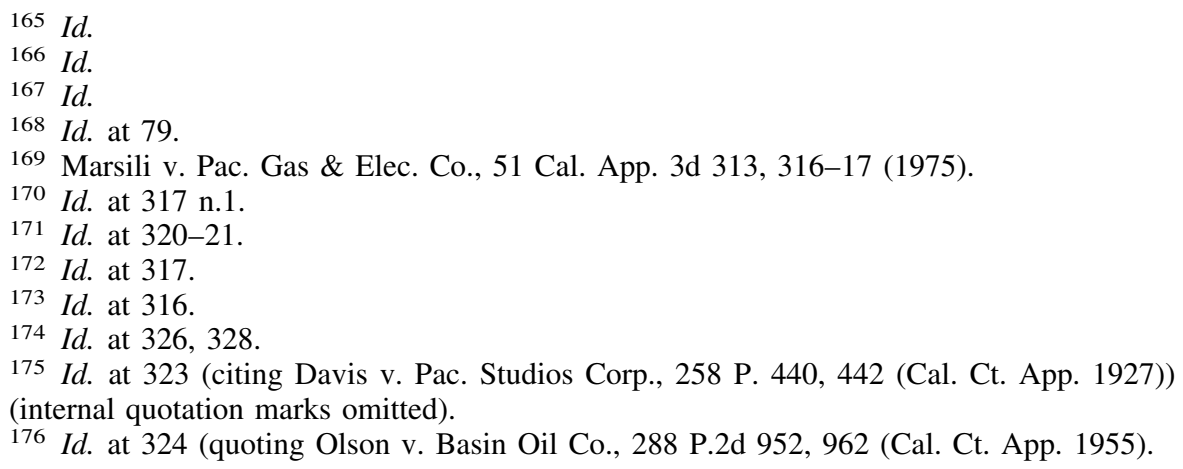


effect on the corporation and had contributed the money based upon the belief that defeating the proposition was in the best interests of the corporation. ${ }^{177}$

\section{iii. The Supreme Court's View}

The Supreme Court has stated in multiple instances that shareholders have the power to challenge corporate independent political expenditures. In First National Bank of Boston v. Belloti, Justice Powell wrote that "[i]n addition to intracorporate remedies, minority shareholders generally have access to the judicial remedy of a derivative suit to challenge corporate disbursements alleged to have been made for improper corporate purposes or merely to further the personal interests of management." ${ }^{178}$ In Austin v. Michigan Chamber of Commerce, Justice Scalia, in a dissenting opinion, stated that a corporation "will risk a stockholder suit if it makes a political endorsement that is not plausibly tied to its ability to make money for its shareholders." ${ }^{179}$ Justice Brennan, concurring with the majority's decision, wrote that "shareholder actions against corporate waste might serve as a remedy for other types of political expenditures that have no legitimate connection to the corporation's business." 180

Most importantly, in Citizens United, Justice Kennedy wrote that "[s]hareholders can determine whether their corporation's political speech advances the corporation's interest in making profits." "Justice Stevens, in a dissenting opinion, wrote that

[t]he structure of a business corporation ... draws a line between the corporation's economic interests and the political preferences of the individuals associated with the corporation; the corporation must engage the electoral process with the aim "to enhance the profitability of the company, no matter how persuasive the arguments for a broader or conflicting set of priorities."182

This line of cases reflects that even though the Supreme Court believes that corporations have the power to spend unlimited sums from their treasuries on advertisements that promote or oppose specific political candidates, the Court also believes that if the expenditures are detrimental to the corporation, shareholders have a judicial remedy based upon the corporate waste doctrine. This is an important point for shareholders to make when challenging corporate independent political expenditures. ${ }^{183}$

177 Id. at 325.

178 First Nat'l Bank of Bos. v. Bellotti, 435 U.S. 765, 795 (1978).

179 Austin v. Michigan Chamber of Commerce, 494 U.S. 652, 691 (1990) (Scalia, J., dissenting).

180 Id. at 678 (Brennan, J., concurring).

181 Citizens United v. Fed. Election Comm'n, 130 S. Ct. 876, 916 (2010).

182 Id. at 974 (Stevens, J., dissenting) (quoting Brief for American Independent Business Alliance as Amicus Curiae 11); see also American Law Institute, Principles of Corporate Governance: Analysis And Recommendations § 2.01(a) (1992) (“[A] corporation ... should have as its objective the conduct of business activities with a view to enhancing corporate profit and shareholder gain.").

183 See infra Part V(A)(1). 


\section{Challenging Corporate Political Expenditures}

It is important to remember that "while companies do not have political preferences, their managers do."184 "Managers may have personal preferences over candidates and parties they wish to support that are simply unrelated to the firm's activities." ${ }^{85}$ Problems arise when political preferences prompt decisions that negatively affect the corporation.

\section{A. Shareholder Arguments}

Based upon the cases cited above and the current law concerning shareholder derivative claims, this Article suggests arguments shareholders should make when challenging independent political expenditures. These arguments include alleging that the independent political expenditures damage the corporation and decrease shareholder return, that the expenditures are in effect corporate gifts, that they are not charitable, and that they serve no corporate purpose.

\section{Independent Political Expenditures Damage Corporations}

Independent political expenditures may damage corporations, both socially and economically, and lead to additional unintended costs for the corporation. "Taking controversial and highly visible political stands can potentially cost clients and therefore lead to financial costs. ... A rise in overt, direct political action by most corporations carries with it risks far exceeding the political gains that might be achieved by acting through other agents." 186 Independent political expenditures "may [also] result in the loss of customers, employee dissatisfaction, or shareholder agitation in the form of proxy fights." 187

As noted above, "political contributions ... bear on the company's reputation as a good corporate citizen." 188 Also, because of "greater political activism by trade groups and demands by candidates and causes for corporate money, boards are now seeing that their corporate image could be tarnished if these contributions or political activities go awry."189 "Imprudent donations can potentially have a major negative impact on company reputations and business

184 Rajesh K. Aggarwal, Felix Meschke \& Tracy Wang, Corporate Political Contributions: Investment or Agency? 3 (AFA 2012 Chicago Meetings Paper, Working Paper, Apr. 5, 2012), available at http://papers.ssrn.com/sol3/papers.cfm?abstract_id=972670.

185 Id. at 10.

186 Justin J. Wert, Ronald Keith Gaddie \& Charles S. Bullock, III, Of Benedick and Beatrice: Citizens United and the Reign of the Laggard Court, 20 Cornell J.L. \& Pub. Pol'y 719, 727 (2011) (citing Michele Micheletti et al., Politics, Products, and Markets: Exploring Political Consumerism Past and Present, 84 Econ. Geography 123, 123-25 (2008); Dietlind Stolle, Marc Hooghe \& Michele Micheletti, Politics in the Supermarket: Political Consumerism as a Form of Political Participation, 26 InT'L Pol. ScI. Rev. 245, 245-69 (2005)).

187 Matthew A. Melone, Citizens United and Corporate Political Speech: Did the Supreme Court Enhance Political Discourse or Invite Corruption?, 60 DePAul L. Rev. 29, 95-96 (2010).

188 Millstein, supra note 134 , at 3.

189 Leslie Wayne, Corporations to Disclose Political Contributions, N.Y. Times Blog (May 29, 2008, 12:49 PM), http://thecaucus.blogs.nytimes.com/2008/05/29/corporations-todisclose-political-contributions/. 
if they don't carefully and fully assess a candidate's positions." ${ }^{190}$ Corporations might contend that this argument is theoretical and can be avoided by greater due diligence in selecting which candidates receive funding. However, independent political expenditures have already tarnished the reputations of some corporations.

For example, in November 2010, Target Corp. (“Target") and Best Buy Corp. ("Best Buy") each provided money, $\$ 150,000$ and $\$ 100,000$ respectively, to MN Forward, a group that ran TV ads supporting state legislator Tom Emmer's gubernatorial bid in Minnesota. ${ }^{191} \mathrm{Mr}$. Emmer was a conservative candidate who opposed same-sex marriage. ${ }^{192}$ Groups and activists supportive of same-sex marriage condemned the donation and even called for boycotts of Target stores. ${ }^{193}$

Target defended the expenditure, stating that the corporation supported Emmer's position on job growth and the state's economy. ${ }^{194}$ Target's CEO, Gregg Steinhafel, wrote that "Target has a history of supporting organizations and candidates, on both sides of the aisle, who seek to advance policies aligned with our business objectives, such as job creation and economic growth." 195 However, with the loss of business caused by the outrage over the donation and reputational harm done, Target was unable to defend the donation as a good business decision and did not provide evidence of any increased profits or increased shareholder returns attributable to the political expenditures. As noted above, based upon these independent political expenditures, Target shareholders proposed a resolution asking the corporation to refrain entirely from political spending. ${ }^{196}$

Support for political candidates is not the only type of independent political expenditure that has damaged corporations. Valero Energy Corporation, Tesoro Corporation, and Occidental Petroleum spent $\$ 4$ million, $\$ 1.5$ million, and $\$ 300,000$ respectively, on California's Proposition $23,{ }^{197}$ a ballot initiative to suspend California's global warming law. ${ }^{198}$ Because of Tesoro's support of Proposition 23, shareholders at Tesoro filed a resolution to request greater dis-

190 Jennifer Martinez \& Tom Hamburger, Target Faces Investor Backlash; Large Shareholders Demand the Retailer Revamp Its Political Contribution Process, L.A. Times, Aug. 20, 2010, at A1.

191 Target Spending Company Money on Candidates, CBS News (Nov. 2, 2010, 8:21 PM), http://www.cbsnews.com/stories/2010/07/27/politics/main6717307.shtml?tag=ContentMain; contentBody.

192 Protecting Life and Marriage, EMMER FOR Governor, http://www.emmerforgovernor. com/issues/socialvalues/ (last visited Nov. 16, 2012).

193 Target Spending Company Money on Candidates, supra note 191.

194 Emily Friedman, Target, Best Buy Angers Gay Customers By Making Contribution to GOP Candidate, ABC News (July 28, 2010), http://abcnews.go.com/Business/target-bestbuy-fire-campaign-contributions-minnesota-candidate/story?id=11270194. 195 Id.

1962012 ISS PREview Report, supra note 121, at 22.

197 Green Century Pressures Occidental over California Prop 23 Support, Green Century Funds (Oct. 13, 2010), http://www.greencentury.com/news/news/Green_Century_Pressures _Occidental_over_California_Prop_23_Support [hereinafter GReEn CEnTURy Funds].

198 Margot Roosevelt, Proposition 23: Backers were Outspent, Out-organized, L.A. TIMES BloG (Nov. 2, 2010, 11:28 PM), http://latimesblogs.latimes.com/greenspace/2010/11/proposition-23-defeat-global-warming-climate-change-initiative.html. 
closure and oversight of political expenditures. ${ }^{199}$ Laura Campos, director of shareholder activities at the Nathan Cummings Foundation, ${ }^{200}$ stated that Tesoro's shareholders were "concerned that Tesoro's support for the highly controversial Proposition 23 could lead to a decrease in shareholder value by damaging the company's reputation and negatively impacting the business environment in a state where Tesoro has significant operations." ${ }^{201}$ Moreover, Tesoro's support for Proposition 23 prompted journalists to dig into the company's environmental record, resulting in news reports that described Tesoro as a "major polluter" 202 and one of the nation's "worst toxic polluters." ${ }^{203}$ It is also worth noting that Proposition 23 did not pass. ${ }^{204}$

What would have been the most likely outcome had Tesoro's shareholders filed a derivative suit claiming that the $\$ 1.5$ million in independent political expenditures supporting Proposition 23 was a waste of corporate assets? The facts here are drastically different than the facts in Stern. ${ }^{205}$ In Stern, the court found that support of the GE/PAC had been effective in building good will with members of Congress and had educated employees on government relations. ${ }^{206}$ In the case at hand, Tesoro derived no net benefit from the independent political expenditures. After all, the Proposition failed to pass, so Tesoro did not receive the consideration that was presumably the goal of its expenditures. ${ }^{207}$

Furthermore, based upon the controversial nature of Proposition 23 and the subsequent negative publicity stemming from support of the law, Tesoro's shareholders could argue that Tesoro did not adequately research the impact those independent political expenditures would have on Tesoro's reputation, even if Proposition 23 would have passed. By contrast, Pacific Gas prevailed against the derivative suit in Marsili in large part because prior to funding the campaign aimed at defeating a state proposition, Pacific Gas had researched the impact that passage of the proposition would have had on the corporation. ${ }^{208}$

For a recent example of damage to corporate reputation, companies such as Coca-Cola and PepsiCo have withdrawn their support for the American Legislative Exchange Council (ALEC). ${ }^{209}$ "ALEC promotes business-friendly leg-

199 Green Century Funds, supra note 197.

200 The Nathan Cummings Foundation is a non-profit organization that provides grants and provides proxy-voting guidelines to shareholders. The Foundation is an institutional shareholder at Tesoro. NATHAN Cummings Foundation, http://nathancummings.org/ (last visited Nov. 17, 2012).

201 Green Century Funds, supra note 197.

202 C. Johnson, Report: Prop 23 Supporters Are Major Polluters, ABC News 10 (Aug. 10, 2010, 3:42 PM), http://www.news10.net/news/local/story.aspx?storyid=90373.

203 Jakada Imani, The Color of Prop 23, S.F. GATE BLOG (Oct. 1, 2010), http://blog.sfgate. com/imani/2010/10/01/the-color-of-prop-23/.

204 See Roosevelt, supra note 198.

205 Stern v. Gen. Elec. Co. (Stern III), 837 F. Supp. 72, 77 (S.D.N.Y. 1993).

206 Id.

207 The Article discusses this point later in the Article and contends that the independent political expenditures would amount to nothing more than corporate gifts. See infra Part V.A.2.

208 Marsili v. Pac. Gas \& Elec., 51 Cal. App. 3d 313, 325 (1975).

209 Peter Overby, Boycotts Hitting Group Behind "Stand Your Ground", NPR (Apr. 5, 2012), http://www.npr.org/2012/04/05/150013705/boycotts-hitting-group-behind-standyour-ground. 
islation in state capitols and drafts model bills for state legislatures to adopt."210 However, the organization has also supported "controversial measures, including voter-identification laws and stand[-]your[-]ground laws."211 Because of the outcry caused by these laws, Kraft and Coca-Cola were urged to withdraw support from ALEC, and subsequently had to make public statements affirming that they would no longer support the group.

\section{i. Decrease in Shareholder Return}

To support a derivative suit, shareholders can also argue, rightfully, that empirical studies have shown that corporate independent political expenditures correlate with lower shareholder returns. A November 2011 study of 12,000 firms found that despite corporate managers' attempts to increase firm value through spending on elections, corporate political spending correlates with lower shareholder value. ${ }^{212}$ The study found that corporations that made independent political expenditures had "operating characteristics consistent with the existence of a free cash flow problem," 213 and that increased expenditures lowered shareholder return. ${ }^{214}$ The study also found that corporations with larger political expenditures evidenced worse corporate governance. ${ }^{215}$ Moreover, the study found no positive effect of donating to winners in presidential or congressional elections ${ }^{216}$ and generally found that donating to either winners or losers is associated with returns that are worse than the returns associated with not donating at all. ${ }^{217}$

The question of whether there has been a waste of corporate assets is a question of fact and does not rest upon any hard-and-fast rule. ${ }^{218}$ However, shareholders have a much stronger argument when relying on empirical evidence showing that political expenditures generally lead to lower shareholder returns.

\section{ii. Lack of Due Diligence}

Shareholders can also argue that their corporation failed to be duly diligent with its independent political spending. These expenditures are generally made without any due diligence. In Marsili, the court found the political expenditures

\footnotetext{
$210 I d$

211 Id.

212 Torres-Spelliscy, supra note 18 , at 9.

213 Aggarwal, supra note 184, at 2.

215 Aggarwal, supra note 184, at 2.

216 Id.

217 Id.

218 Schreiber v. Carney, 447 A.2d 17, 27 (Del. Ch. 1982).
}

214 Id. See also Anne Tucker, Rational Coercion: Citizens United and a Modern Day Prisoner's Dilemma, 27 GA. St. U. L. Rev. 1105, 1130 n.67 (2011) (citing John C. Coates, IV, Corporate Governance and Corporate Political Activity: What Effect Will Citizens United Have on Shareholder Wealth? 16 (Harvard John M. Olin Ctr. for L., Econ., and Bus., Discussion Paper No. 684), available at http://ssrn.com/abstract=1680861 ("[C]orporate political activity correlate[s] with weak corporate governance, it also correlates (negatively) with firm value. Firms with corporate governance provisions giving shareholders more power to engage in less political activity. Corporations that engage in political activity generate lower value for their shareholders relative to the value of the assets they control.")). 
to be valid, in part, because Pacific Gas had researched the detrimental effect the ballot initiative would have had on the corporation and made the contribution based upon its belief that the contribution was in the best interests of the corporation. ${ }^{219}$ Shareholders can cite to examples such as the Target and Tesoro situations, discussed earlier in the Article, to show that companies must be aware of the possible negative consequences of making independent political expenditures. ${ }^{220}$

\section{Independent Political Expenditures as Corporate Gifts}

Shareholders can argue that corporate independent political expenditures are, in effect, corporate gifts. A corporate gift is a payment that is completely unsupported by consideration. ${ }^{221}$ Courts examine whether the payment was so unreasonably disproportionate to the benefits created by the exchange that a reasonable person would think the corporation did not receive any benefit. ${ }^{222}$ "When a director or officer removes or diverts corporate assets for which the corporation receives no benefit, then the director or officer breaches the duty of loyalty and is liable for waste of corporate assets." ${ }^{.23}$ In Orloff $v$. Shulman, a Delaware court held that corporate waste exists when a benefit is "so inadequate that no person of ordinary sound business judgment would deem it worth that which the corporation paid." 224 In Union Pacific Railroad Co. v. Trustees, Inc., the Utah Supreme Court upheld a \$5,000 charitable donation and held that a contribution will be valid as long as it is "designed to assure a present or foreseeable future benefit to the corporation." 225 Delaware courts also "adhere[] to the well[-]settled common law principles of corporate law that 'directors have no power to give away corporate property,' and that a gift of corporate assets requires unanimous stockholder approval." 226

An example of political spending that can potentially be labeled a corporate gift is Tesoro's support of California Proposition 23, which was discussed earlier in this Article. ${ }^{27}$ Tesoro spent $\$ 1.5$ million in support of a ballot initiative that ultimately failed.228 Tesoro appears to have no good argument that it received any consideration for the expenditure. Shareholders can argue that Tesoro spent \$1.5 million and received nothing in return; therefore, the political expenditure was in effect a corporate gift. ${ }^{229}$ Shareholders can further distin-

219 Marsili v. Pac. Gas \& Elec., 51 Cal. App. 3d 313, 326 (1975).

220 See supra Part V(A)(1).

221 Michelson v. Duncan, 407 A.2d 211, 217 (Del. 1979).

222 Int'l Ins. Co. v. Johns, 874 F.2d 1447, 1461 (11th Cir. 1989) (citing Fidanque v. Am. Maracaibo Co., 92 A.2d 311, 321 (Del. Ch. 1952)).

223 Henderson v. Axiam, Inc., No. 96-2572-D, 1999 Mass. Super. LEXIS 580, at *162 (Mass. Super. Ct. June, 22 1999) (citing Coggins v. New Eng. Patriots Football Club, Inc., 397 Mass. 525, 537 (1986)).

224 Orloff v. Shulman, No. Civ. A. 852-N, 2005 WL 3272355, at*11 (Del. Ch. Nov. 23, 2005).

225 Union Pac. R.R. Co. v. Trs., Inc., 329 P.2d 398, 402 (Utah 1958).

226 Taussig v. Wellington Fund, Inc., 187 F. Supp. 179, 211-12 (D. Del. 1960).

227 See supra Part V(A)(1).

228 Green Century Funds, supra note 197; see also Margot Roosevelt, Prop. 23 Battle Marks New Era in Environmental Politics, L.A. Times (Nov. 4, 2010), http://articles.latimes. com/2010/nov/04/local/la-me-global-warming-20101104.

229 See Orloff, 2005 WL 3272355, at*11 n.75. 
guish from the facts of Wrigley because Tesoro suffered reputational damage by supporting a controversial ballot initiative. ${ }^{230}$

Shareholders can also argue that independent political expenditures do not reasonably assure that the corporation will receive the benefits contemplated by those expenditures. ${ }^{231}$ In Kerbs v. California Eastern Airways, a stock option plan was held to be invalid when the option could be exercised immediately after its issuance. There was nothing in the plan which reasonably assured the corporation that it would receive the benefits contemplated by it. ${ }^{232}$ Shareholders can analogize the giveaway in Kerbs to corporations' independent political expenditures. They can also argue that just as with stock option plans that can be exercised immediately, independent political expenditures cannot be reasonably certain to provide the benefit corporations seek by making the expenditures.

Shareholders can emphasize that unlike some market conditions that can be predicted with some certainty, ${ }^{233}$ a political candidate's platform to get elected could vary drastically from what the politician actually accomplishes in office. Shareholders can argue that political candidates' positions on issues in the past can, and often do, change based upon the political climate. For example, assume that a car manufacturer spends $\$ 5$ million on advertisements supporting a candidate for President of the United States, because that candidate has stated his support for the automobile manufacturing industry. ${ }^{234}$ What, if any, assurance does the corporation have that the candidate will still favor the auto industry once that candidate becomes President? Moreover, what if the candidate does not win the election? Shareholders can rightfully argue that if the candidate does not win the election, the corporation is deprived of any intended benefit of the independent political expenditures, i.e., the election of the candidate as president and his favorable support for the automobile industry. Shareholders might even be able to argue that the money spent against the eventual winner made him and his administration even less likely to propose or support legislation and policies favored by the company and the auto industry as a whole.

Shareholders may face difficulty when bringing these claims because courts have generally found themselves to be "ill-fitted to attempt to weigh the 'adequacy' of consideration under the waste standard or, ex post, to judge appropriate degrees of business risk." ${ }^{235}$ However, when the board of directors' decision cannot be attributed to a rational business purpose, a court may substi-

230 See Johnson, supra note 202; see also Imani, supra note 203.

231 See Kerbs v. Cal. E. Airways, Inc., 90 A.2d 652, 656 (Del. 1952).

232 Id. at 657.

233 For example, if prices of crude oil rise, consumers and investors can expect gas prices to rise along with it. Another example is that when a company announces lower than expected earnings, its stock price can be expected to drop.

234 The $\$ 5$ million figure is realistic in light of other companies' actual expenditures. Aetna Inc., for example, spent more than $\$ 11$ million in lobbying and political expenditures in 2011. See Sean P. Carr \& Wayne Dalton, Aetna Led Insurers in 2011 Lobbying Spending, Funded Pro-GOP Group, SNL FInANCIAL (June 4, 2012), http://www.citizensforethics.org/ page/-/PDFs/Legal/Letters/6-14-12_Aetna_Letter_Exhibits.pdf?nocdn=1.

235 In re The Limited, Inc. S'holders Litig., No. 17148-NC, 2002 Del. Ch. LEXIS 28, *33 (Del. Ch. Mar. 27, 2002). 
tute its judgment for that of the board. ${ }^{236}$ Therefore, shareholders must allege that the independent political expenditures "[were] so completely bereft of consideration that [they] effectively constituted a gift." 237

\section{Independent Political Expenditures Are Not Charitable}

Shareholders should argue that independent political expenditures are not made for the purpose of benefitting the community and do not generate "good will." This is an essential distinction shareholders need to make when challenging independent political expenditures. It is important for shareholders to note that corporate political expenditures are not treated like charitable contributions under the Internal Revenue Code ("IRC"). ${ }^{238}$

Corporate political expenditures are taxed under the IRC, Section 162. ${ }^{239}$ Corporate political expenditures such as lobbying activities, independent political expenditures, and indirect political expenditures are all non-deductible under the provisions of the IRC. ${ }^{240}$

This is an important distinction. The legislature and the courts view charitable contributions much differently than political expenditures. For example, in Cammarano v. United States, the Supreme Court upheld a Treasury Regulation that denied business expense deductions for political expenditures. ${ }^{241}$ In Regan v. Taxation with Representation, the Supreme Court held that Congress was not required by the First Amendment to subsidize political expenditures. ${ }^{242}$ Justice Rehnquist has even written, albeit in a dissent, that "[i]t cannot be so readily concluded that the right of political expression is equally necessary to carry out the functions of a corporation organized for commercial purposes."243 Furthermore, the shareholders' argument for waste of corporate assets is stronger for corporate political speech than it is for charitable contributions because political expenditures are not tax-deductible, whereas charitable contributions may be. ${ }^{244}$

The non-tax deductible status of political expenditures should be a critical point made by shareholders when challenging the validity of independent political expenditures. Shareholders should use the reasoning in the Kahn and Henderson cases to support their argument. In Kahn, the court's finding that the donation was reasonable was based, in part, on the tax benefits to the corpora-

236 See Frankel v. Am. Film Techs., 675 N.Y.S.2d 837, 840 (N.Y. Sup. Ct. 1998); see also McDermott v. Superior Court, 83 Cal. App. 4th 378, 383 (2000).

237 The Limited, 2002 Del. Ch. LEXIS 28, at*33 (quoting Ash v. McCall, No. 17132, 2000 Del. Ch. LEXIS 144, at*19-20 (Del. Ch. Sept. 15, 2000)).

${ }^{238}$ Compare I.R.C. $§ 162(\mathrm{e})$ (2006) (political expenditures), with I.R.C. $§ 170$ (2006) (charitable contributions).

239 I.R.C. § 162(e).

240 See id.; see also Internal Revenue Serv., Dep't of the Treasury, Pub. No. 529, Miscellaneous Deductions 16 (2011), available at http://www.irs.gov/pub/irs-pdf/p529. pdf (Corporations cannot "deduct contributions made to a political candidate [or] campaign committee.").

241 Cammarano v. United States, 358 U.S. 498, 513 (1959).

242 Regan v. Taxation with Representation, 461 U.S. 540, 546 (1983).

243 First Nat'l Bank of Bos. v. Bellotti, 435 U.S. 765, 825 (Rehnquist, J., dissenting).

244 Compare I.R.C. $\$ 162(\mathrm{e})$ (2006) (political expenditures), with I.R.C. § 170 (2006) (charitable contributions). 
tion. ${ }^{245}$ In Henderson, the court found that the charitable contribution was reasonable because the tax deduction conferred a benefit upon the corporation. ${ }^{246}$

Corporations will also have a hard time arguing that independent political expenditures generate "good will" in the community. As discussed earlier in the Article, many independent political expenditures are not reported to shareholders or the business community, whereas charitable contributions are generally extolled in the corporation's annual report or in some other form of public notice. ${ }^{247}$ In Board of Supervisors v. Virginia Electric \& Power Co., the Virginia Supreme Court held that a refusal to make charitable donations "might bring on the loss of the good will of the community it serves, while other businesses make donations for worthy causes." ${ }^{248}$ In Union Pacific Railroad Co., the Utah Supreme Court held that "[c]orporate donations create good will in the community." 249 This author found no case where a court has stated that by not making independent political expenditures, a corporation will lose "good will" in the community, and, as evidenced earlier in this Article, controversial political expenditures may even damage a corporation's reputation. ${ }^{250}$

\section{Independent Political Expenditures Serve No Corporate Purpose}

Shareholders can argue that independent political expenditures have no corporate purpose and that the expenditures are, in fact, examples of corporate officers and directors using corporate treasury funds to further their own personal political goals and therefore these expenditures are prohibited. In Stern, the court not only looked at the benefit to the corporation provided by the challenged expenditures, but also the purpose of those expenditures. ${ }^{251}$

Even though directors have wide discretion to run the corporation, courts have found that "a judge does his duty by ensuring that business decisions, whatever their merit, were undertaken by a director without consideration of his self-interest or for the sake of some third-party." ${ }^{252}$ The court in In re INFOUSA also held that

a skilled litigant, and particularly a derivative plaintiff, recognizing the institutional advantages and competency of the judiciary reflected in [Delaware] law, places before the Court allegations that question not the merit's [sic] of a director's decision, a matter about which a judge may have little to say, but allegations that call into doubt the motivations or the good faith of those charged with making the decision. $^{253}$

In Guth v. Loft, the court stated that corporate officers and directors have the "duty, not only affirmatively to protect the interests of the corporation committed to his charge, but also to refrain from doing anything that would work

245 Kahn v. Sullivan, 594 A.2d 48, 61 (Del. 1991).

246 Theodora Holding Corp. v. Henderson, 257 A.2d 398, 405 (Del. Ch. 1969).

247 Jill E. Fisch, How Do Corporations Play Politics?: The FedEx Story, 58 V And. L. Rev. 1495, 1563 (2005) ("The visibility of corporate political activity, on an issue specific basis, is happenstance and sporadic, depending largely on individual press reports.").

248 Bd. of Supervisors v. Va. Elec. \& Power Co., 87 S.E.2d 139, 149 (Va. 1955).

249 Union Pac. R.R. Co. v. Trs., Inc., 329 P.2d 398, 401 (Utah 1958).

250 See supra Part V(A)(1).

251 Stern v. Gen. Elec. Co. (Stern III), 837 F. Supp. 72, 77 (S.D.N.Y 1993).

252 In re INFOUSA, Inc. S'holders Litig., 953 A.2d 963, 984 (Del. Ch. 2007).

253 Id. 
injury to the corporation, or to deprive it of profit or advantage." ${ }^{254}$ Shareholders, therefore, should focus on directors' motivations behind independent political expenditures made in support of political candidates.

Shareholders can also argue that courts may infer directors' adverse interests in their failure to disclose political expenditures to the shareholders and the public. As noted above, "[p]olitical contributions are generally not disclosed to the board or shareholders, nor are political expenditures generally subject to oversight as part of a corporation's internal controls." ${ }^{255}$ In Feinberg Testamentary Trust $v$. Carter, shareholders brought a derivative action for breach of fiduciary duty in connection with the corporation's repurchase of stock. ${ }^{256}$ The U.S. District Court for the Southern District of New York held that the adverse interest of the directors was

indicated by their subsequent failure to disclose the . . transaction to the public and the shareholders. If the directors had believed the [transaction] represented an appropriate expenditure of corporate funds, one would have expected the directors to announce the full details of the transaction to shareholders. Instead, the directors followed a continued policy of refusing to discuss ... the transaction. ${ }^{257}$

In a derivative suit, shareholders should emphasize any lack of transparency of corporate independent political expenditures and aim to persuade the court to view the corporate independent political expenditures "as . . . atypical situation[s] where the self-interest of corporate directors may well have dominated other considerations." 258

\section{ISSUES FOR THE COURTS}

Because of Citizens United and increased corporate political spending, courts will begin to see more shareholder derivative claims challenging independent political expenditures. ${ }^{259}$ This section analyzes issues that will arise for courts when deciding these cases. These issues include defining, on a case-bycase basis, what a "benefit" to the corporation is and also determining whether the challenged corporate political expenditure had a "corporate purpose." This section also suggests approaches courts can take when deciding these cases. In Stern, the court formulated a two-part test for analyzing political expenditures. ${ }^{260}$ The test is a good starting point, but Stern was decided in the preCitizens United era and could not foresee corporations making independent

254 Guth v. Loft, 5 A.2d 503, 510 (Del. 1939).

255 Fisch, supra note 96, at 1613.

256 Feinberg Testamentary Trust v. Carter, 652 F. Supp. 1066, 1068-69 (S.D.N.Y. 1987).

257 Id. at 1074. This premise has also been adopted by courts in Delaware. See Grobow v. Perot, 526 A.2d 914, 923 (Del. Ch. 1987) ("of considerable significance, the . . directors [in Feinberg] had failed to disclose the [transaction] . . in proxy materials sent to shareholders, causing the District Court to observe that, had the directors believed that the . . transaction represented 'an appropriate expenditure of corporate funds, one would have expected [them] to announce the full details . . . to shareholders.' ").

258 Feinberg, 652 F. Supp. at 1075.

259 See Public Citizen, supra note 22, at 14.

260 Stern v. Gen. Elec. Co. (Stern III), 837 F. Supp. 72, 77 (S.D.N.Y. 1993). 
political expenditures from the corporate treasury in the amounts we have seen in the past two years. ${ }^{261}$

\section{A. Defining "Benefit" to the Corporation}

The first and most challenging question courts will face is how to define if a corporation receives a benefit from an independent political expenditure. A good place to start is to look at the definition of "benefit." Ballentine's Law Dictionary defines "benefit" as "whatever adds value to property; advantage; profit . . . or enhances the value of . . . property rights."262 Black's Law Dictionary defines "benefit" as an "advantage," "privilege," "profit," or "gain."263

As stated earlier in this Article, courts examine whether payments were so unreasonably disproportionate to the benefits created by the exchange that a reasonable person would think the corporation did not receive any benefit. ${ }^{264}$ This issue is made more complicated by the fact that the benefits derived from independent political expenditures are not always immediately apparent. Courts have also voiced their reluctance to "second-guess" the decision-making process of corporate directors. ${ }^{265}$ However, courts have implied that they might substitute their judgment for that of the board of directors if the board's decision cannot be attributed to any rational business purpose. ${ }^{266}$

When looking at claims alleging corporate waste, courts must decide whether a corporation received a benefit for political expenditures. The court can impose a "reasonable person" standard as outlined in INFOUSA ${ }^{267}$ and Lewis v. Vogelstein. ${ }^{268}$ The court in INFOUSA held that courts must "apply a reasonable person standard and deny a claim of waste wherever a reasonable person might deem the consideration received adequate." ${ }^{269}$ The court further held that

[w] hen this difficult standard is applied in the liberal context of a motion to dismiss, in order for the complaint to survive the motion, the Court must find that in any of the possible sets of circumstances inferable from the facts alleged under the complaint, no reasonable person could deem the received consideration adequate. ${ }^{270}$

261 See Schouten, supra note 23; see also Dan Eggen, Most Independent Ads for 2012 Election Are from Groups that Don't Disclose Donors, WAsH. Post (April 24, 2012, 6:28 AM), http://www.washingtonpost.com/politics/most-independent-ads-for-2012-election-are-fromgroups-that-dont-disclose-donors/2012/04/24/gIQACKkpfT_story.html.

262 Ballentine's Law Dictionary 131 (3d ed. 1969). See also Technomedical Labs, Inc. v. Utah Sec. Div., 744 P.2d 320, 324 (Utah Ct. App. 1987) (Definition of benefit not limited to monetary benefit.).

263 Black's Law Dictionary 178 (9th ed. 2009).

264 See, e.g., Int'l Ins. Co. v. Johns, 874 F.2d 1447, 1461 (11th Cir. 1989) (citing Fidanque v. Am. Maracaibo Co., 92 A.2d 311, 321 (Del. Ch. 1952)).

265 See, e.g., In re Cox Radio, Inc. S'holders Litig., No. 4461-VCP, 2010 WL 1806616, at *14 (Del. Ch. May 6, 2010) ("While hindsight is generally 20/20, it cannot be used to second guess the business judgment of Delaware directors . . ..").

266 See, e.g., Unocal Corp. v. Mesa Petroleum Co., 493 A.2d 946, 954 (Del. 1985) (citing Sinclair Oil Corp. v. Levien, 280 A.2d 717, 720 (Del. 1971)).

267 In re INFOUSA, Inc. S'holders Litig., 953 A.2d 963, 1002 (Del. Ch. 2007).

268 Lewis v. Volgelstein, 699 A.2d 327, 336 (Del. Ch. 1997).

269 In re INFOUSA, 953 A.2d at 1002 (citing Apple Computer, Inc. v. Exponential Tech., Inc., 1999 WL 39547 (Del. Ch. Jan. 21, 1999)).

270 Id. 
The court in Vogelstein held that a claim for corporate waste requires allegations of "an exchange of corporate assets for consideration so disproportionately small as to lie beyond the range at which any reasonable person might be willing to trade." 271

For courts to decide whether an independent political expenditure was "reasonable," courts should employ an approach analogous to the test developed in Henderson. ${ }^{272}$ In Henderson, the court held that the test to determine the validity of a corporate donation is a test of reasonableness and that "the provisions of the Internal Revenue Code pertaining to charitable gifts by corporations furnish a helpful guide." 273 The IRC provides that the total deductions for a corporation for any taxable year shall not exceed 10\% of the corporation's taxable income. ${ }^{274}$ Even though independent political expenditures are not taxdeductible, the Henderson test could provide a starting point for the court's analysis.

Courts could also apply a cost-benefit analysis. In Henderson, the court found that the small loss of immediate income, had it not been for the gift in question, was far outweighed by the overall benefits from the gift. ${ }^{275}$ Courts could examine whether a corporation performed any cost-benefit analysis before making any independent political expenditure. Courts could employ the use of experts to make determinations as to whether, based upon a cost-benefit analysis, the corporate independent political expenditures were valid exercises of business judgment.

Another approach the courts can take to ascertain whether independent political expenditures are reasonable is a net loss test. This test is developed from the net loss rule defined in Miller v. American Telephone \& Telegraph Co. ${ }^{276}$ In Miller, the Third Circuit Court of Appeals held that a shareholder derivative suit must allege that a transaction caused independent damage to the corporation. ${ }^{277}$ In Wrigley, the Illinois Appellate Court held that the shareholders' claims failed, in part, because they did not allege any damage to the corporation stemming from the failure to install lights at Wrigley Park. ${ }^{278}$ For shareholders to be successful under the net loss test, they must show that the independent political expenditure damaged the corporation. Damage to the corporation could include loss of profits, decreased shareholder return, or even

271 Vogelstein, 699 A.2d at 336; In re Lear Corp. S'holder Litig., 967 A.2d 640, 656 (Del. Ch. 2008) ("If given the facts pled in the complaint, 'any reasonable person might conclude that the deal made sense, then the judicial inquiry ends.' " (quoting Harbor Fin. Partners v. Huizenga, 751 A.2d 879, 892 (Del. Ch. 1999) (internal quotations omitted)); see also Weiss v. Swanson, 948 A.2d 433, 450 (Del. Ch. 2008) (“"A] waste entails an exchange of corporate assets for consideration so disproportionately small as to lie beyond the range at which any reasonable person might be willing to trade.").

272 See Theodora Holding Corp. v. Henderson, 257 A.2d 398, 405 (Del. Ch. 1969); see also supra Part III.B.3.

273 Henderson, 257 A.2d at 405.

274 I.R.C. $\S 170(\mathrm{~b})(2)(\mathrm{A})(2006)$.

275 Henderson, 257 A.2d at 405.

276 See Miller v. Am. Tel. \& Tel. Co., 507 F.2d 759, 763 (3d Cir. 1974).

277 See id. at 763 \& n.5.

278 Shlensky v. Wrigley, 237 N.E.2d 776, 780 (Ill. App. Ct. 1968). 
damage to the corporation's image due to support of a political candidate. ${ }^{279}$ For example, both the Target and Tesoro situations described earlier in this Article evidence the type of reputational harm that corporations can suffer from making controversial independent political expenditures. ${ }^{280}$

\section{B. Defining "Business Purpose"}

The second question courts must answer is whether the independent political expenditure was made for a "business purpose." Directors and officers should not spend corporate funds on political issues that further their political objectives rather than those of the corporation. ${ }^{281}$

One approach the courts can take is the "in-the-line-of-business" test drawn from Guth v. Loft. ${ }^{282}$ The definition of "in the line of business" is "not within the field of precise definition, nor is it one that can be bounded by a set formula. It has a flexible meaning, which is to be applied reasonably and sensibly to the facts and circumstances of the particular case." 283

Where a corporation is engaged in a certain business, and an opportunity is presented to it embracing an activity as to which it has fundamental knowledge, practical experience and ability to pursue, which, logically and naturally, is adaptable to its business having regard for its financial position, and is one that is consonant with its reasonable needs and aspirations for expansion, it may be properly said that the opportunity is in the line of the corporation's business. ${ }^{284}$

For example, if a hard drive manufacturing corporation spent $\$ 500,000$ on advertisements supporting a candidate who had never shown great support for the technology industry, or if the corporation spent that money on a candidate who wanted to impose more regulation on that industry, the corporation will have a hard time contending that the independent political expenditures were for a valid "business purpose."

Another approach the courts can take is drawn from a two-part test for characterization of a transaction for tax purposes in Klamath Strategic Inv. Fund v. United States. ${ }^{285}$ Under this approach, the first question courts have to answer would be whether the independent political expenditure was made to maximize profits. This analysis would be both objective and subjective. ${ }^{286}$ An independent political expenditure would have a business purpose if there was an objective reasonable opportunity for economic profit or benefit to corporate reputation. ${ }^{287}$ The second question the courts would have to answer would be whether the expenditure was motivated by something other than the political ideology of the directors. As noted above, courts can infer director motivations from the facts and circumstances of the corporate political expenditures. ${ }^{288}$

279 See Technomedical Labs, Inc. v. Utah Sec. Div., 744 P.2d 320, 324 (Utah Ct. App. 1987) (definition of "benefit" not limited to monetary benefit).

280 See supra Part V.A.1.

281 Fisch, supra note 96, at 1609-10.

282 Guth v. Loft, Inc., 5 A.2d 503, 514 (Del. 1939).

283 Id.

284 Id.

285 See Klamath Strategic Inv. Fund v. United States, 568 F.3d 537, 544-45 (5th Cir. 2009).

286 See id. at 544.

287 Gefen v. Comm'r, 87 T.C. 1471, 1490 (1986).

288 See Feinberg Testamentary Trust v. Carter, 652 F. Supp. 1066, 1075 (S.D.N.Y. 1987). 
What we can learn from these tests is that the analyses for finding the benefit of a corporate independent political expenditure and examining the motivation behind making these expenditures will be closely intertwined. The benefit and motivation questions will generally be decided upon the same set of facts, and courts will have to look at the totality of the circumstances of the expenditures, rather than looking at the expenditures piecemeal. Courts should recognize that a corporate fiduciary should not serve both corporate and personal interests at the same time. ${ }^{289}$ " [C]orporate fiduciaries "owe their whole duty to the corporation, and they are not to be permitted to act when duty conflicts with interest. They cannot serve themselves and the corporation at the same time.' "290

\section{Improving Corporate Political Expenditure Policies}

Corporations can decrease the risk of facing a shareholder derivative complaint by improving the transparency of independent political expenditures and improving policies governing those expenditures. Corporations should have a stated policy for political spending and also a committee that can monitor the political expenditure program.

\section{A. Proposed Model for Political Expenditures}

The Center for Political Accountability ("CPA") has constructed a "Model Code of Conduct" for corporate political spending. ${ }^{291}$ Having a political spending model is very important for a corporation especially since "[c]ompanies ... . have paid record fines, run up hefty legal bills and faced reputational knocks . . . because of political expenditures." 292 The CPA cites a study conducted in 2006 by Mason-Dixon Polling \& Research ("Mason-Dixon Study") which "found that 85 percent of shareholders agreed that the "lack of transparency and oversight in corporate political activity encourages behavior' that threatens shareholder value and 'puts corporations at legal risk." "293 The CPA cites to this study to illustrate the importance of a written corporate political spending model.

The CPA Model Code provides suggestions for companies to improve their policies concerning political expenditures. ${ }^{294}$ It provides suggestions for improvement in areas such as, transparency, proper motivation, and proper monitoring of political expenditures. ${ }^{295}$ The section below builds upon the CPA Model Code, providing not only examples of companies whose corporate

289 Ne. Harbor Golf Club, Inc. v. Harris, 661 A.2d 1146, 1150 (Me. 1995).

290 Id.

291 See Bruce F. Freed \& Jamie Carroll, Open Windows: How Codes of Conduct Regulate Political Spending and a Model Code to Protect Company Interests and SHAREHOlder VAlue (2007), available at http://www.politicalaccountability.net/index.php? $\mathrm{ht}=\mathrm{A} /$ GetDocumentAction/i/611 [hereinafter CPA Model CodE].

292 Id. at 1.

293 Id. (citing Ctr. Political Accountability, Corporate Political Spending: A SurVey of American Shareholders 6 (2006) (survey conducted by Mason-Dixon Polling \& Research).

294 Id. at 2.

295 See id. 
policies should be emulated, but also guidance on how to implement these policies in an effective and efficient manner.

\section{Political Motivations}

The fact that companies do not have political preferences-but their managers and directors do-is not lost on shareholders. ${ }^{296}$ Nearly $75 \%$ of shareholders "believe that corporate political spending is often undertaken to advance the private political interests of corporate executives rather than the interest of the company and its shareholders." ${ }^{297}$ The CPA Model Code calls for political activities of employees and management to be explicitly separated in a corporation's stated political giving policies. ${ }^{298}$

For example, Hewlett Packard Corporation's ("HP") contribution policy encourages its "employees to be active in their communities," but states that "the company limits political activities on company time and premises." 299 Merck \& Co., Inc. ("Merck"), states in its Code of Conduct that "[e]mployees should not use the workplace to demonstrate their personal support for a particular political issue, party or candidate." 300

A codification of this policy could state the following: "The Corporation is committed to being actively involved in the political process. The Corporation will not make any direct independent expenditures on behalf of candidates running for public office unless there is a reasonable belief that the expenditures will benefit The Corporation. Under no circumstances will independent political expenditures be made to advance the private political interests of corporate executives or directors." This may seem like a common sense statement, but it will serve as written notice so that an executive cannot later claim to have been unaware of the corporation's policy on political expenditures.

As an additional measure, for independent political expenditures exceeding a certain dollar amount, corporations would be required to attach a short statement affirming that expenditure's purpose. For example, any independent political expenditure greater than $\$ 25,000$ should have a documented purpose. Assume that a computer manufacturer spends $\$ 5$ million on advertising to support a Congressional candidate. The corporation would state that it supported the candidate because of his pledge to support the technology industry while in office. As long as the candidate has actually pledged support for the technology industry, this could negate later claims alleging that the political expenditures were made for an improper purpose. These statements could be contained in a secure database maintained by the corporation. The database would be accessible by the officers, directors, and legal counsel for the company.

296 Aggarwal, supra note 184, at 3.

297 CPA Model Code, supra note 291, at 21.

298 Id.

299 HP Political Contributions Policies, HP.com, http://www.hp.com/hpinfo/abouthp/government/us/engagement/policies.html?jumpid=Reg_R1002_USEN (last visited Nov. 17, 2012).

300 Merck, Code of Conduct 17 (3d ed.), available at http://www.merck.com/about/code _of_conduct.pdf. 


\section{Clearly Defined Criteria for Funds Spent on Political Activities}

Corporations must have clearly defined criteria for making political contributions. These criteria will lessen the chance that any independent political expenditures will be challenged after the fact. HP has a model list of criteria for deciding which political candidates to support. ${ }^{301}$

Corporations should first look at the support for their business priorities and ask themselves, "Does this candidate support the corporation either directly or indirectly by supporting the corporation's industry?" The likelihood that the candidate will support the corporation should be the main factor when deciding whether to support a certain political candidate. The next criterion is whether the candidate engages in bi-partisan activity. ${ }^{302}$ If the candidate has a record of, or evinces a strong commitment toward, working with candidates on both sides of the political spectrum, there is less chance that the candidate will be persuaded to vote along strict party lines.

Another criterion is that a corporation should favor moderate politicians over partisan extremists. ${ }^{303}$ Only spending corporate funds to support moderate candidates lessens the chance of donating to a polarizing political figure who will stir up negative publicity or cause the corporation to lose public and shareholder support. Additionally, to further reduce the chance of becoming embroiled in scandals, corporations should only donate to politicians who have shown high levels of ethics. ${ }^{304}$ If a corporation supports a politician who has not shown high levels of ethics in the past, the corporation could be criticized for its support.

Corporations should also use criteria to determine the amount of money they spend on support for a candidate. The first criterion is the likelihood of changing the outcome of a political contest. For example, a corporation should not spend millions of dollars on a candidate who is so far behind in credible pre-election polls that he is extremely unlikely to win. Outcomes of political races do have frenetic swings; however, there will be closer scrutiny of large amounts of money spent on candidates who have very little chance of winning. In other words, the corporation needs to be able to show that it carefully picked its battle and was not, in effect, throwing away money on a race that its candidate, in all likelihood, could not win. Another criterion is that if a candidate is the incumbent, what leadership positions does he or she hold? For example, it is more understandable for banks to support the re-election of an incumbent who is chairman of the Senate Committee on Banking, Housing, and Urban Affairs than it would be if those banks supported a candidate who does not hold such a position. These are just some criteria that should determine whether corporate funds should be spent to support a political candidate and the amount that should be spent. As noted above, corporations must always remember that the most important criterion will always be whether the candidate supports the corporation either directly or indirectly.

301 HP Criteria for Assessing Candidates, Hp.CoM, http://www.hp.com/hpinfo/abouthp/ government/us/engagement/criteria.html (last visited Nov. 17, 2012).

302 Id.

303 Id.

304 Id. 


\section{Public Disclosure of Corporate Funds Spent on Political Activities}

"Investor activists want companies to disclose how they spend corporate treasury money on politics not only because this is their money, but also because of their generally-held [sic] belief that political spending can pose risks to shareholder value." ${ }^{305}$ The Mason-Dixon study found that $94 \%$ of shareholders want corporations to disclose all political expenditures. ${ }^{306}$ Transparency in political spending can also discourage improper expenditures and promote openness and honesty. ${ }^{307}$ The CPA Model Code calls for corporations to disclose all expenditures of corporate funds on political activities to shareholders. ${ }^{308}$

Three major corporations provide examples of such disclosure efforts. Publicly available pages of HP's corporate website include a detailed chart of political contributions. ${ }^{309}$ The chart lists the candidate, committee, or organization receiving the political expenditure, the political party with which each is affiliated, the district that a candidate would represent if elected, and the amount of the political expenditure. ${ }^{310}$ The chart separates the expenditures by state to make it easier to see where the expenditures are being made. Likewise, Merck semi-annually posts political contributions categorized by state, candidate, and amount on its corporate responsibility website, which is available to the public. ${ }^{311}$ Merck also discloses any political contributions to committees known as 527 organizations ${ }^{312}$ and contributions to IRC section 501c(4) organizations. ${ }^{313}$ Since 2008, Merck has also disclosed the portion of dues that major U.S.-based trade associations report to Merck as being used for advocacy and/or political activities. ${ }^{314}$ Aetna Inc. ("Aetna") takes a different approach,

305 Welsh \& Young, supra note 90, at 31 (citing Bruce F. Freed \& John C. Richardson, Ctr. Political Accountability, The Green Canary: Alerting Shareholders and Protecting Their Investments 5 (2005), available at http://www.politicalaccountability. net/index.php?ht=A/GetDocumentAction/i/920).

306 CPA Model Code, supra note 291, at 21-22 (citing Ctr. Political Accountability, Corporate Political Spending: A Survey of American Shareholders (2006) (survey conducted by Mason-Dixon Polling \& Research).

307 Id. at 21.

308 Id.

309 See HP Corporate Contributions, HP.com, http://www.hp.com/hpinfo/abouthp/government/us/engagement/corporate.html (last visited Nov. 17, 2012).

310 Id.

311 Transparency Disclosures, MERCK, http://www.merckresponsibility.com/focus-areas/ ethics-and-transparency/transparency-disclosures/home.html (last visited Nov. 17, 2012).

312 Id. A political organization regulated under Section 527 of the IRC. The term "political organization" means a "party, committee, association, fund, or other organization (whether or not incorporated) organized and operated primarily for the purpose of directly or indirectly accepting contributions or making expenditures, or both, for an exempt function." I.R.C. $§ 527(\mathrm{e})(1)(2006)$.

313 Transparency Disclosures, supra note 311; I.R.C. § 501(c)(4) (2006) (“[c]ivic leagues or organizations not organized for profit but operated exclusively for the promotion of social welfare, or local associations of employees, the membership of which is limited to the employees of a designated person or persons in a particular municipality, and the net earnings of which are devoted exclusively to charitable, educational, or recreational purposes"). 314 Transparency Disclosures, supra note 311. 
providing a yearly "Political Contributions and Related Activity Report" to the public on its corporate website. ${ }^{315}$

Corporations should provide the public with an easily accessible, detailed chart of political expenditures on their corporate websites. This chart would allow corporations to easily distribute information concerning their political expenditures to the public. Using the HP political expenditures chart as a template, corporations should include all material information such as the candidate, committee, or organization receiving the political expenditure, the political party with which each is affiliated, the targeted jurisdiction, and, of course, the amount of the political expenditure. In addition to this information, corporations' website disclosure charts should include a written description of the purpose for independent political expenditures greater than $\$ 25,000$. This chart will be very important for corporations to avoid shareholder derivative lawsuits. As noted above, a lack of transparency can result in courts inferring that improper motivations of directors underlie those directors' independent political expenditures. ${ }^{316}$

\section{Monitoring Corporate Funds Spent on Political Activities}

Corporations need to have mechanisms in place to monitor corporate spending on political activity. The CPA Model Code calls for directors to oversee corporate political spending, receive regular reports from corporate officers responsible for the spending, and meet regularly with officers to review the purpose of the expenditures. ${ }^{317}$ The need for such reports and meetings is reflected in the findings of The Conference Board study, discussed earlier in this Article: $73 \%$ of the directors surveyed wrongly believed that corporations were required to report all their political spending, and 38\% were unaware that political spending does not require board approval. ${ }^{318}$

Examples of companies that have strong political expenditure monitoring programs include The Williams Companies, Inc. ("Williams"), which requires board approval for any company funds or assets used for political purposes. ${ }^{319}$ McDonald's Corp. ("McDonald's") requires all political contributions to be approved in advance by the head of its Government Relations Department. ${ }^{320}$ In addition, "any [p]olitical [c]ontributions to a single candidate, political party or ballot initiative that will aggregate to more than . . \$100,000 in a calendar year ... require the approval of the McDonald's area of the world president of the market in which the contribution will be made." 321

315 Aetna PaC \& Aetna Inc., Political Contributions and Related Activity Report (2009), available at http://www.aetna.com/about-aetna-insurance/document-library/pac/ 2009-Aetna-PAC-annual-report.pdf.

316 See Feinberg Testamentary Trust v. Carter, 652 F. Supp. 1066, 1073-75 (S.D.N.Y. 1987).

317 CPA Model Code, supra note 291, at 24.

318 Corporate Political Handbook, supra note 97, at 19.

319 Williams, Williams Code of Business Conduct 8-9 (2012), available at http://williamscom.files.wordpress.com/2012/03/cbc.pdf.

320 Political Contribution Policy, AвoutmCDonalds.com, http://www.aboutmcdonalds. $\mathrm{com} / \mathrm{mcd} /$ investors/corporate_governance/guidelines_and_policies/Political_Contribution_ Policy.html (last visited Nov. 17, 2012).

321 Id. 
Corporations also should create a Political Spending Compliance Committee ("PSCC") to implement and monitor corporation's political expenditures. ${ }^{322}$ The PSCC should be led by a representative from a corporation's law department or office of the general counsel. It should be a cross-functional group of executives that ensures all independent political expenditures are in compliance with company policy, are reasonably assured of benefitting the corporation, and serve a valid corporate purpose. No money should be spent on a political campaign without prior approval from the corporation's PSCC.

The PSCC also will be responsible for maintaining a database for all political expenditures, including information concerning the purpose of independent political expenditures greater than $\$ 25,000$. The members of the PSCC must be given specific training concerning political expenditures and must continually attend trainings and seminars to stay abreast of current developments in the area of campaign finance and political spending regulations and should meet bi-monthly to discuss implementation of compliance and ethics initiatives. ${ }^{323}$

\section{Conclusion}

With its ruling in Citizens United, the Supreme Court cleared the way for unlimited independent political expenditures by corporations. In 2012, the Court had a chance to revisit the Citizens United holding, but refused to do so and all attempts by Congress to limit or reverse Citizens United have failed to date. One key question this raises is: Where does this leave shareholders? “ 'Corporate money' in a publicly traded company is in part made up of investments from shareholders. Thus, corporate spending is[,] in reality[,] the spending of investors' money[;]"324 and shareholders, therefore, have a strong interest in not allowing the corporation to waste assets and expend large amounts of corporate treasury funds in support of political candidates that do not benefit the corporation. For these reasons, the issue of whether and how shareholders may be able to control independent political expenditures will be part of the legal discussion for the foreseeable future.

This Article has provided ample evidence that even though corporations have the ability to make independent political expenditures, it is not always in their best interest to do so. Moreover, this Article has discussed how shareholders may bring derivative claims to challenge corporate independent political expenditures that they believe are detrimental to the corporation. After all, shareholders are considered the "owners" of a corporation and therefore are given rights at the expense of other corporation constituents. ${ }^{325}$

Granted, shareholders must meet a high burden for a claim of corporate waste to succeed; however, by using the suggestions provided throughout this

322 This idea comes from an earlier article where I espoused the creation of a Charitable Contributions Compliance Committee. See William Alan Nelson II, No Good Deed Goes Unpunished: Charitable Contributions and the Foreign Corrupt Practices Act, 17 FordHAM J. CoRP. \& FIN. L. 54 (forthcoming Spring 2012), available at http://ssrn.com/sol3/papers. cfm?abstract_id=1884283.

323 Id.

324 See Torres-Spelliscy, supra note 18, at 5.

325 Roberta S. Karmel, Should a Duty to the Corporation Be Imposed on Institutional Shareholders?, 60 Bus. Law. 1, 1 (2004). 
Article, shareholders have a much greater chance of success. Shareholders can argue that empirical studies have shown that corporate independent political spending leads to lower shareholder return, that corporate independent political spending serves no corporate purpose, that corporate political spending can harm a corporation's reputation, and that corporate political expenditures are not treated like charitable contributions under the tax code.

On the other hand, corporations can also take steps to largely immunize themselves from derivative suits that allege corporate waste based upon corporate political spending. Derivative suits are less likely to succeed if corporations implement a comprehensive political spending program, specifically including clear policies concerning oversight and disclosure of a corporation's political spending, and creation of a Political Spending Compliance Committee ("PSCC") to monitor the corporate political spending policies.

In conclusion, the debate over not just the merits and effectiveness of corporate political spending, but about what limits should be imposed on such spending, continues in several arenas, most visibly in the campaigns themselves and in Congress. While that dialogue plays out, however, the debate can and should be resolved in courtrooms and boardrooms. Those corporations that are not transparent about their political spending, and cannot justify their independent political expenditures as likely to benefit the corporation, will find themselves losing derivative suits filed by shareholders who are fighting for the best interests of the corporation. 